\title{
Plant-Level Responses to Antidumping Duties: Evidence from U.S. Manufacturers ${ }^{1}$
}

\author{
Justin Pierce ${ }^{2}$ \\ Center for Economic Studies, U.S. Census Bureau
}

April 2009

\begin{abstract}
This paper describes the effects of a temporary increase in tariffs on the performance and behavior of U.S. manufacturing establishments (plants). Using antidumping duties as an example of temporary protection, I compare the responses of protected manufacturers to those predicted by new models of trade with heterogeneous firms. I find that apparent increases in revenue-based productivity associated with temporary protection are primarily due to increases in prices and mark-ups. In fact, antidumping duties lower physical productivity among the set of protected plants reporting output data in units of quantity. Moreover, antidumping duties allow for the continued operation of low-productivity plants that likely would have otherwise ceased production. As a result, temporary protection slows the process of output rationalization, with less productive plants producing a greater share of total output, leading to a reduction in aggregate productivity growth. Importantly, plants that are denied protection by the government are no more likely to exit than protected plants. Rather, they adjust by dropping the unprotected product and producing other, potentially higher-productivity products.
\end{abstract}

JEL Classification: F13, F14, D24

Keywords: Antidumping; Temporary Protection; Heterogeneous Firms; Productivity

${ }^{1}$ I thank Rod Ludema, Anna Maria Mayda and Brad Jensen for continuous support and guidance. This paper also benefited from helpful suggestions from Peter Schott, Andrew Bernard, Meredith Crowley and Stephen Redding, as well as seminar participants at Georgetown University and the Center for Economic Studies. Jim Davis provided timely help with disclosure of results. Any remaining errors are my own. The research in this paper was conducted while the author was a Special Sworn Status researcher at the U.S. Census Bureau, Center for Economic Studies. Any opinions and conclusions expressed herein are those of the author and do not necessarily represent the views of the U.S. Census Bureau. All results have been reviewed to ensure that no confidential information is disclosed. Support for this research at the Washington RDC from NSF (ITR-0427889) is also gratefully acknowledged.

24600 Silver Hill Road, Washington, DC 20233, tel: 301-763-6469, email: justin.r.pierce@census.gov. 


\section{Section 1: Introduction}

What are the effects of temporary tariff protection on U.S. manufacturers? This question has become increasingly important as antidumping duties have become one of the primary forms of trade protection, in the U.S. and world-wide. Moreover, the answers to this question have implications that reach beyond antidumping policy. Studying U.S. manufacturers’ reactions to antidumping duties can also provide new insight into the heterogeneous responses of firms to changes in tariff rates, within the context of a major trade shock in a developed country. This paper provides the first micro-level evidence on the effects of antidumping duties in the United States, using a dataset that includes the full population of U.S. manufacturing establishments (plants). Furthermore, through the use of output data measured in units of quantity, I am able to detect substantial differences between the effects of antidumping duties on plants’ physical and revenue productivities.

While antidumping duty rates can reach into the triple digits and drastically alter trade flows, there are disagreements about some of their most fundamental implications, including their effect on firm and plant-level productivity. On one hand, there is a substantial literature that suggests that any increase in tariffs should decrease productivity. In Melitz (2003), an increase in tariffs_ - or a failure to decrease tariffs_-allows for the continued operation of lowproductivity firms that would have otherwise exited, resulting in a decrease in mean firm-level productivity. In addition, Bernard, Redding and Schott (2006), describe a channel for withinplant productivity growth during trade liberalization, which arises when plants drop their least productive products and reallocate resources to their most productive products. Pavcnik (2002) and Fernandes (2007) (for developing countries) and Bernard, Jensen and Schott (2006) (for the 
U.S.) provide empirical evidence showing that productivity and nominal tariffs are negatively correlated.

In contrast, there is evidence that tariff protection—-particularly temporary protection— can increase firm or plant-level productivity by increasing the incentive to invest in new technology. Matsuyama (1990) was among the first to show that temporary protection can speed up the time of technology adoption, while noting that the government's threat to remove protection if the domestic firm fails to invest is not credible. Similarly, Miyagiwa and Ohno $(1995,1999)$ show that protection can induce investment in a fixed cost technology by increasing the market share of domestic firms. These theoretical models are supported by empirical results in Konings and Vandenbussche (2008) showing that revenue-based productivity increased among E.U. manufacturers receiving temporary antidumping protection. ${ }^{3}$ As noted in that paper, however, increases in revenue productivity can be caused not only by increases in physical productivity, but also by increases in prices and mark-ups.

I examine these issues by comparing the behavior of a treatment group of plants that received protection to three control groups of plants in similar industries that did not receive protection. As described below, these control groups are constructed in a manner that eliminates two potential sources of bias: a self-selection bias that exists if industries that apply for protection differ from those that do not apply and a "government-selection bias" that arises if the government bases its decision of whether to provide protection on variables that are correlated with productivity. I employ a difference-in-difference estimator to estimate the effect of

${ }^{3}$ Konings and Vandenbussche (2008) find that antidumping duties were associated with increases in mean plant-level productivity. An important additional result is that antidumping duties allowed for technological catch-up by the least productive firms, while firms with high exante productivities experienced productivity declines. 
antidumping protection, which nets out time-invariant differences between the treatment and control groups, as well as macro-level shocks affecting the treatment and control groups identically. In addition, I examine whether variation in the effective antidumping duty rate protecting plants leads to heterogeneous responses to protection.

I find that the effect of antidumping duties on plant-level productivity depends crucially on whether output is measured in revenue or physical units of quantity. While antidumping protection is associated with an increase in plant-level revenue productivity, these increases are driven primarily by increases in prices and mark-ups. ${ }^{4}$ Antidumping duties actually lower physical productivity among the set of protected plants reporting output data in units of quantity. These results underscore the importance of differentiating between revenue and physical productivity—a distinction that has received relatively little attention in the field of international trade. In fact, this distinction is particularly important when considering the case of antidumping duties, since increases in prices and markups would likely be taking place at the same time as changes in physical productivity.

Antidumping duties also provide a useful way of examining some of the best-known results from the heterogeneous-firm literature. In particular, while most empirical research on the responses of firms to trade liberalization has focused on developing countries, antidumping protection can provide an example of a major trade shock in a large, developed country-in this case, the United States. Moreover, in many heterogeneous-firm models, trade liberalization increases aggregate productivity as resources are shifted from less-productive to more-productive

\footnotetext{
${ }^{4}$ I examine the effect of antidumping duties on both prices and mark-ups, since mark-ups will be less responsive to antidumping protection if suppliers are able to extract rents from protected plants through higher prices.
} 
uses. By studying the imposition of antidumping duties, it is possible to examine whether some of these newly-recognized benefits of trade liberalization are eliminated when protection is imposed.

One well-documented way that trade liberalization reallocates resources from low to high-productivity uses is through the exit of the least productive firms. In the theoretical literature, exit of low-productivity firms during trade liberalization is a key result of Melitz (2003), Bernard, Eaton, Jensen and Kortum (2003) and Bernard, Redding and Schott (2006). These theoretical results are also supported by robust empirical evidence. Pavcnik (2002) and Bernard, Jensen and Schott (2006) have shown that decreases in trade costs bring about the exit of low-productivity firms and plants, yielding substantial increases in aggregate productivity. To examine whether antidumping protection slows this process, I compare the probability of exit among a treatment group of plants that received antidumping protection to that in a control group of unprotected plants.

Bernard, Redding and Schott (BRS) $(2006,2008)$ identify an additional channel for resource reallocation and productivity growth during trade liberalization, through productswitching by multi-product firms. BRS (2006) provide models of firms with exporting and production, where overall firm productivity is a combination of firm and firm-product components. Trade liberalization yields productivity growth by forcing firms to drop marginally productive products and by forcing the least productive firms to exit. ${ }^{5}$ But if antidumping

${ }^{5}$ BRS (2006) provides a useful framework for examining how multi-product firms react to changes in trade policy. There are, however, important differences between the framework in BRS (2006) and the temporary antidumping protection examined in this paper. First, BRS (2006) is based explicitly on a multilateral trade liberalization occurring as two countries move from a closed economy to an open-economy equilibrium. In antidumping duty proceedings, changes in trade policy are unilateral and are targeted against imports from a particular country. 
protection allows low-productivity plants to continue producing low-productivity products, it will have negative effects on both plant-level and aggregate productivity. I examine the effect of antidumping duties on plants' product-switching activities by comparing the probability of dropping protected products in the treatment group to the probability of dropping products that did not receive protection in the control group.

I find that antidumping duties allow for continued production by low-productivity plants that would have otherwise stopped producing. Importantly, this effect manifests itself not through decreased plant-level exit, but rather through a reduction in product-switching among protected plants. Protected plants are no less likely to exit than those that did not receive protection. But while low-productivity plants that are turned down for antidumping duties by the government react by dropping products, protected plants are able to continue producing the same products. As a result, antidumping duties likely decrease the productivity gains that would otherwise occur as a result of product-switching.

By allowing for continued production by low-productivity plants, antidumping duties may eliminate the benefits of trade liberalization associated with output rationalization, where high-productivity plants increase their market share at the expense of low-productivity plants. I measure this effect by decomposing aggregate productivity into mean plant-level productivity and a term that measures the degree to which higher-productivity plants produce a larger share of output, as in Olley and Pakes (1996). I find that antidumping protection slows the process of output rationalization, decreasing aggregate productivity growth. While the degree of output

Second, BRS (2006) focuses on trade liberalization for all products. Antidumping duty investigations, on the other hand, involve a single product or a set of closely related products. Third, the trade liberalization in BRS is permanent, while antidumping duties are temporary. 
rationalization is significantly higher among protected plants prior to receiving protection, the control group of unprotected plants steadily increases its level of output rationalization as the antidumping duties set in. By the end of the period of analysis, the control group has overtaken the treatment group, to exhibit a higher level of output rationalization.

The remainder of the paper is organized as follows. Section 2 describes the data. Section 3 provides a brief discussion of the antidumping investigation process in the United States, as well as a description of the products typically involved in antidumping investigations. Section 4 describes the empirical strategy and reports results. Section 5 concludes.

\section{Section 2: Data}

This analysis uses plant-level and plant-product-level ${ }^{6}$ data from the U.S. Census Bureau's (Census) Longitudinal Research Database (LRD) for the years 1987 to 1997. Total factor productivity is calculated using data from the Census of Manufactures (CMF). The CMF contains plant-level data on output (value of shipments and sometimes quantity), as well as input data including the number of production and non-production employees, raw material usage, investment, depreciation and book value of capital. The CMF is conducted every five years, in years ending in two and seven (e.g. 1987, 1992, 1997) and all U.S. manufacturers, regardless of size, are required by law to respond. ${ }^{7}$

\footnotetext{
${ }^{6}$ Plant-product-level data refers to output data for every product produced at every plant. These shipment data are measured in revenue for all products and in units of physical quantity for a subset of products.

${ }^{7}$ The CMF collects a limited set of data from small manufacturers, referred to in the data as "administrative records." Since input usage data may be imputed for administrative records, they have been excluded from the analysis. This exclusion of administrative records is standard in research employing the LRD. See, e.g. Bernard, Redding and Schott (2008).
} 
An important benefit of the CMF is the availability of output data measured in units of quantity for certain products. The availability of quantity-based output data allows for the calculation of physical productivity—in addition to the standard revenue productivity—as well as average unit prices and price-cost mark-ups. The ability to examine physical productivity, prices and mark-ups is extremely important when studying antidumping duties, since changes in physical productivity are likely accompanied by increases in prices and mark-ups. These quantity-based output data have been used in recent studies examining the differences between revenue and physical productivity, including Foster, Haltiwanger and Syverson (2008).

It is important to define a number of terms that will be used throughout this paper. The term plant refers to a manufacturing establishment, which is a production facility located at a single physical location. Products and industries are 5-digit and 4-digit categories of the Standard Industrial Classification (SIC), respectively. ${ }^{8}$ A product group is the set of plants producing a particular product. Lastly, an investigated product is a product that was involved in an antidumping investigation, regardless of the outcome of the investigation.

The use of plant-level data is an important innovation of this paper and provides many advantages over more aggregated data, even including firm-level data. Many firms involved in petitioning for antidumping protection are large multi-product manufacturers. In fact, some firms participated as petitioners in multiple antidumping investigations involving multiple products. Individual plants on the other hand, tend to produce a much narrower set of products than firms as a whole. The use of plant-level data, therefore allows for much more accurate matching between the products named in contingent protection investigations and the facilities that actually produce those products.

\footnotetext{
${ }^{8}$ The 1987 SIC contains 459 four-digit industries and 1,848 five-digit products.
} 
The benefits of plant-level matching can be seen clearly by examining the experience of a specific firm, the integrated steel-maker United States Steel. According to its 2006 annual report, U.S. Steel operated 24 plants in the United States, producing multiple products including flat-rolled sheets, tin mill, strip mill plate, galvanized sheets and tubular products. ${ }^{9}$ Moreover, several of U.S. Steel's products have been subject to antidumping or countervailing duty protection over the years including Corrosion-Resistant Carbon Steel Flat Products (1993), Cut to Length Plate (1979, 2003), Seamless Pipe (1995), Oil-Country Tubular Goods (1995), HotRolled Steel Products (2001) and Welded Large-Diameter Line Pipe (2001, 2002) ${ }^{10}$ In the case of U.S. Steel, firm-level data are not sufficient for defining when or in what way the firm received protection. With plant-level data, however, I am able to identify the plants producing the specific products covered by antidumping duties applied in specific years.

In addition, I am able to greatly refine the identification of plants that did and did not receive contingent protection through the use of plant-product-level data contained in the LRD. These data report the full list of products manufactured at each plant, as well as the value, and sometimes quantity, of shipments attributable to each product. The availability of this plantproduct-level data represents an additional level of disaggregation beyond the "major industry" codes generally used to identify plants and firms in micro-level datasets.

\footnotetext{
${ }^{9}$ United States Steel at 32. Available online at: http://www.uss.com/corp/investors/annual_reports/2006-annual-report.pdf

${ }^{10}$ United States Steel at 15-16. http://www.uss.com/corp/investors/annual_reports/2006-annualreport.pdf
} 
The list of products involved in antidumping investigations in the United States is from version 3.0 of Chad Bown's Global Antidumping Database. ${ }^{11}$ Products subject to antidumping investigations are identified using the Harmonized Tariff System (HTS) and products may be defined from the 4-digit level to the 10-digit level. ${ }^{12}$ In addition to a description of the products involved in each investigation, the antidumping database provides the dates and outcomes of each phase of the investigation—e.g. preliminary and final injury and dumping determinationsalong with the final remedy. The analysis in this paper considers the effects of antidumping investigations that were completed during the period from 1988 to 1996. This setup ensures that I am able to observe plant-level outcomes both before and after the imposition of protection for every product group. ${ }^{13}$ Lastly, because successful antidumping investigations in the United States almost always result in ad-valorem tariffs_-rather than price undertakings or suspension

${ }^{11}$ Available online at http://people.brandeis.edu/ cbown/global_ad/.

12 Although the HTS was not effective until 1989, investigations in Bown's Global Antidumping Database that ended in 1988 were assigned HTS numbers, ex-post.

${ }^{13}$ Because products in antidumping investigations are classified under the HTS, while products in the LRD are classified under the SIC, it is necessary to concord the two product classification systems. The matching of HTS codes to SIC codes takes place through a set of SIC Base Codes (SICBase) developed by Census. SICBase codes are a bridge that connects the HTS-where products are defined solely based on their physical characteristics - to the SIC, where products are also classified based on their method of production. For this reason, Census assigns a single SICBase to each HTS10. This SICBase may contain a single SIC5 if the HTS10 is a subset of a single SIC5, or multiple SIC5s if the HTS10 fits several SIC5 categories. Using a three step process, I am then able to determine which plants produce products that were involved in antidumping investigations:

Step 1: SICBase codes are assigned to the HTS10 codes contained in the antidumping dataset (referred to here as BOWN_AD for brevity) using an HTS10-SICBase concordance (HTS_SICBase) published by the Census Bureau.

Step 2: SICBase codes are assigned to each SIC5 in the plant-product-level data in the LRD using a SIC5-SICBase concordance known as the Principle Differences file (PD). The 1992 principle differences file, which is used for the analysis in this paper can be found online at http://www.census.gov/epcd/www/intronet.html.

Step 3: The BOWN_AD antidumping dataset is merged to the LRD using the SICBase codes. 
agreements-I am able to study the effect of variation in the antidumping duty rate on productivity.

\section{Section 3: Antidumping Duties in the United States}

Under GATT Article VI and the WTO’s Antidumping Agreement, WTO members are permitted to impose discriminatory tariffs on goods sold by foreign producers at prices that are deemed to be less than fair value (LTFV), if these sales result in material injury to the domestic industry. In the United States, sales are considered to be made at LTFV—i.e. dumped — when a foreign firm sells a good in the United States at a price that is below that offered on comparable sales in its home market, or below its average total cost (ATC). ${ }^{14}$

Antidumping investigations in the United States are initiated by individual firms, trade associations or sometimes labor unions, which are referred to in antidumping investigations as petitioners. The foreign firms selling allegedly dumped merchandise are referred to as respondents. Petitioners apply for antidumping protection by submitting a petition to the Import Administration of the Department of Commerce (DOC) and the International Trade Commission (ITC). The DOC determines whether sales made by foreign firms in the U.S. are being made at LTFV. The ITC determines whether the U.S. industry has been injured as a result of the dumping.

14 There are additional subtleties to the LTFV determination. For market economies, the preferred price comparison is between sales by the foreign producer in the U.S. and its home market. If there are insufficient sales in the foreign producer's home market, U.S. prices are compared to sales in a third country. If there are insufficient sales in the third country, U.S. prices are compared to the "constructed value (CV)" of the foreign producer's merchandise, which is gathered from the firm's cost accounting system and is essentially ATC. Sales made by firms in non-market economies are always compared to the "normal value (NV)" the firm's merchandise, which is again essentially the firm's ATC. 
If the DOC finds that sales have been made at LTFV and the ITC concludes that these sales have injured U.S. producers, an ad-valorem tariff is placed on imports of goods from the respondents' home countries. This ad-valorem tariff, which is known as an antidumping duty is equal to the percentage difference between the U.S. price and the home-market price or ATC. I refer to the magnitude of the antidumping duty as the antidumping duty rate. Because the antidumping duty is applied to all dumped goods, it benefits the petitioners, as well-as nonparticipating producers of the investigated product.

Table 1 reports the types of products involved in antidumping investigations from 1988 to 1996, showing the number of antidumping duty investigations by 2-digit HTS Chapter. The most frequent seekers of antidumping duties were producers of "Iron and Steel" (Chapter 72) and “Articles of Iron and Steel” (Chapter 73). Other active applicants for antidumping protection included producers of machinery and appliances (Chapters 84 and 85), inorganic and organic chemicals (Chapters 28 and 29) and transportation vehicles and parts (Chapter 87). As these examples indicate, antidumping duties are primarily used to protect relatively homogenous manufactured goods.

Table 2 shows the number of antidumping investigations completed, by outcome for the years 1980 to 2005. The number of antidumping investigations tends to increase during and immediately following periods of recession, and we see that this phenomenon did, in fact, occur following the recession of 1990-1991, when the number of new investigations spiked in 1991 and 1992. Aside from this countercyclical trend in new investigations, the period from 1988 to 1996 was typical in terms of the number of investigations initiated.

\section{Section 4: Empirical Strategy and Results}

Pre-Estimation Definitions 


\section{$\underline{\text { A. Definition of Treatment and Control Groups }}$}

To borrow terms from the program analysis literature, I conduct this analysis by comparing the behavior of plants in a treatment group receiving antidumping protection to plants in a control group that do not. The treatment group consists of plants producing products that applied for and received antidumping protection. Each plant in the treatment group is assigned a date of treatment and an ad-valorem duty rate, ${ }^{15}$ which comes from the results of the antidumping investigation associated with the product it produces. If a plant produces more than one product that receives protection, the treatment date and duty are those associated with the product that accounts for the highest share of its output.

Comparing the behavior of these treated plants to a control group-rather than simply examining changes in treated plants over time-allows for netting out changes in plant-level variables that are independent of the treatment. Using the difference-in-difference framework described in more detail below I am also able to net out macro-level shocks that affect all manufacturers equally.

In the framework being examined in this paper, a natural concern is that any estimated treatment effects could be affected by a self-selection bias, because the set of plants that apply for antidumping protection are almost certainly different from those that do not. For example, antidumping applicants produce goods that are subject to import competition, perceive themselves as being injured by imports and operate in industries capable of cooperating to file a case.

15 Of the 160 antidumping investigations initiated between 1988 and 1996, 5 ended with suspension agreements. For these cases, no ad-valorem antidumping duty rate was available. 
To control for this self-selection bias, I use an approach employed in Konings and Vandenbussche (2008) to define a first control group. Specifically, I define the control group to be plants producing products that applied for antidumping duties, but were denied protection by the government. I will refer to this control group as the termination control group, hereafter. As with treated plants, plants in the termination control group produce products characterized by high import competition, perceive themselves as injured by imports and are able to organize the industry to file an antidumping petition. Moreover, as shown in Table 3, control plants are concentrated in the same sectors that successfully apply for protection-especially primary and fabricated metals, and industrial and electronic equipment. ${ }^{16}$ In addition, as described in Table 4, plants in the treatment and control groups are comparable in terms of their total value of shipments, number of employees and capital to labor ratios. Importantly, they also display nearly identical mean levels of total factor productivity and labor productivity in the pretreatment year of 1987.

Despite the similarity of the treatment and control groups, there is a possibility of an additional "government selection bias," if the government only grants protection to petitioners that meet certain criteria. In particular, the ITC considers variables such as employment and import penetration when deciding whether to provide protection in antidumping investigation. Because these variables are likely correlated with productivity, estimates based on the termination control group may be biased.

${ }^{16}$ Observations where the treatment and control groups overlap have been dropped from the analysis. Overlapping of treatment and control groups can occur for two reasons. First, a single SIC5 product could receive protection from one antidumping investigation but be denied protection in another. This is possible if the HTS10 products defined in two different antidumping investigations both map into the same SIC5. In addition, a single plant could produce two products, where one product receives protection and the other is turned down for protection. 
I control for this potential government selection bias by constructing two alternative control groups composed of unprotected industries that are similar to protected industries in terms of the variables considered by the ITC in antidumping investigations. Specifically, these two alternative control groups, which I will refer to as the "matched control groups" are formed by estimating a probability of protection based on industry-level independent including lagged import penetration, lagged employment, GDP growth, labor productivity and price growth. ${ }^{17}$ Each matched control group is composed of plants in industries with a high predicted probability of protection, but that did not actually receive protection.

The first matched control group—matched control group 1 -is formed by estimating the probability of receiving antidumping protection for all industries. This means that every industry that did not receive protection has the potential to be included in matched control group 1 , including industries that never applied for protection and those that applied, but were turned down by the government. Matched control group 1 is formed by estimating a multinomial logit model where the dependent variable takes a value of 1 if an industry never applied for protection, 2 if it applied and was turned down and 3 if it applied for and received protection. Independent variables are the determinants of protection considered by the ITC and described above. Matched control group 1 is then the set of plants in industries that had a probability of protection greater than the $75^{\text {th }}$ percentile of that in protected industries, but that did not receive protection. ${ }^{18}$

${ }^{17}$ These variables have been used to explain the probability of receiving antidumping protection in Blonigen and Park (2004) and Konings and Vandenbussche (2008).

${ }^{18}$ This is the same probability cutoff used to form a matched control group in Konings and Vandenbussche (2008). 
Matched control group 2 is formed by only considering industries that applied for protection. A logit model is estimated where the dependent variable equals 1 for industries that received protection and 0 for industries that applied for but did not receive protection. Independent variables are the same as those considered when constructing matched control group 1. The control group is composed of plants in industries did not receive protection but that were in the top $75^{\text {th }}$ percentile in terms of their predicted probability of protection. Matched control group 2 has the attractive property of being composed of plants in industries that applied for protection - thus controlling for potential self-selection bias-while also being highly similar to the treated industries, in terms of the variables considered by the ITC.

Results of the multinomial logit and logit regressions used to create the two matched control groups are reported in Table A.1 of Appendix 1. Estimated coefficients take the expected sign and are consistent with results in Blonigen and Park (2004) and Konings and Vandenbussche (2008). Specifically, the probability of receiving antidumping protection increases with higher levels of import penetration, employment and labor productivity. In contrast, higher GDP growth and price growth are associated with lower probabilities of receiving protection.

\section{B. Productivity Measures}

I calculate productivity in two ways. The first is the superlative TFP index from Caves et al. (1982). As described in Aw, Chen and Roberts (2001), this TFP expression measures the performance of each plant, relative to a hypothetical plant producing the mean level of output with the mean level of inputs, within an industry, in the base period, $1987 .{ }^{19}$ The TFP index

\footnotetext{
19 This measure of total factor productivity is standard in the trade and productivity literatures and has been used in other studies including Bernard, Redding and Schott (2008).
} 
therefore incorporates a plant's deviation of output and inputs from the industry mean in any given year, but also from the mean in the base period. This calculation yields a TFP measure that is comparable across plants and years:

(1) $\ln T F P_{p t}^{i}=\left(\ln Y_{p t}^{i}-\ln \bar{Y}_{t}^{i}\right)+\sum_{s=2}^{t}\left(\ln \bar{Y}_{t}^{i}-\ln \bar{Y}_{t-1}^{i}\right)$

$$
\begin{aligned}
& -\left[\sum_{m} \frac{1}{2}\left(S_{m p t}^{i}+\bar{S}_{m t}^{i}\right)\left(\ln X_{m p t}^{i}-\ln \bar{X}_{m t}^{i}\right)\right. \\
& \left.+\sum_{s=2}^{t} \sum_{m} \frac{1}{2}\left(\bar{S}_{m t}^{i}+\bar{S}_{m t-1}^{i}\right)\left(\ln \bar{X}_{m t}^{i}-\ln \bar{X}_{m t-1}^{i}\right)\right]
\end{aligned}
$$

I construct the TFP index expressed in Equation (1) for each plant $p$ in year $t$ using the set of inputs $m=\{$ Capital, Raw Materials, Production Workers, Non-Production Workers $\}$. The superscript $i$ indicates that mean variables are calculated at the SIC4 industry level. $X_{m p t}^{i}$ is the expenditure of plant $\mathrm{p}$ in time $\mathrm{t}$ on input $\mathrm{m}$ and $S_{m p t}^{i}$ is the share of input $\mathrm{m}$ in total revenue. I calculate average input usage and shares at the industry-year-level. Therefore, $\bar{S}_{m t}^{i}, \ln \bar{Y}_{t}^{i}$ and $\bar{X}_{m t}^{i}$ are the arithmetic means of industry-level input shares, revenue and input expenditure, respectively.

The second measure of productivity is a simple, single-factor labor productivity, defined as the real total value of sales (RTVS) per employee:

(2) $L P_{p t}=\frac{R T V S_{p t}}{T E_{p t}}$

where $T E_{p t}$ is the total number of employees at plant $\mathrm{p}$ at time t. Labor productivity is used primarily as a robustness check for the results based on total factor productivity. All results reported in this paper hold for both TFP and labor productivity. 
Semi-parametric estimators, including those developed by Olley and Pakes (1996) and Levinsohn and Petrin (2003) have been used extensively in recent papers studying the effects of changes in trade policy on TFP. ${ }^{20}$ As has been established in this literature, these methods can be useful for correcting the simultaneity bias that arises when plants with high TFP consume more inputs and the selection bias associated with only observing surviving plants. These methods are not well-suited for use with the economic census data employed in this paper, however, due to their use of lagged input values in the TFP calculation. While it could be useful to calculate TFP using one of these semi-parametric methods if annual data were available, I will note that Van Biesebroeck (2004) finds that TFP measures derived from various methods tend to be highly correlated.

\section{Deflation}

Whenever productivity is calculated using either revenue or value-added data-i.e. data that contain both a price and a quantity component—it is important to separate changes in prices and mark-ups from changes in true productivity. This separation becomes critically important when mark-ups and productivity could move in the same direction, as in the situation examined in this paper. While some have suggested that antidumping duties can increase productivity, through their influence on technology adoption decisions, they almost certainly lead to higher mark-ups as well. Without an adjustment to account for changes in mark-ups, an increase in prices resulting from antidumping protection would show up as an increase in observed total factor productivity. This means that the results are biased toward finding a positive correlation between antidumping protection and revenue TFP.

${ }^{20}$ See, for example, Pavcnik (2002), Fernandes (2008) and Konings and Vandenbussche (2008). 
The CMF, which collects output data in units of quantity for a subset of plants is uniquely suited for separating changes in prices and mark-ups from changes in physical productivity. In instances in which quantity data are available, physical quantities can be used as a measure of plant-level output and incorporated into the calculation of physical productivity, without deflation.

When calculating revenue productivity, I control for changes in mark-ups- to the extent possible — by deflating revenue using industry-level price indexes, applied to the set of products produced at each plant. This technique results in a plant-level deflator that is constructed by weighting the industry-level deflators according the share of a plant's output that is assigned to that industry. Industry-level output deflators, as well as industry-level deflators for cost of materials and capital are from the NBER-CES Manufacturing database reported in Bartelsman, Becker and Gray (2000).

There are at least two ways in which these plant-level deflators are insufficient for completely separating changes in mark-ups from changes in true productivity. First, since they are based on average price indexes, they do not allow for heterogeneity in pricing across plants. In this sense, plants that charge high prices_-due to high local market power, for examplewould be misinterpreted as high-productivity plants. Second, because the price indexes are calculated at the industry, rather than the product level, they will not fully reflect increases in product-level prices. This higher level of aggregation means that revenue-based productivity measures will overstate productivity growth in situations where mark-ups are increasing, as is likely the case in the situation considered in this paper.

\section{Effective Antidumping Duty Rates}


A single antidumping investigation can be filed against imports from multiple countries and if the case ends with a determination by the DOC and ITC to offer protection, each country may be assigned a different ad-valorem antidumping duty. Naturally, imports from certain countries account for larger shares of U.S. imports of a good than others. In order to account for the true importance of an antidumping duty on U.S. trade, therefore, I calculate an effective antidumping duty rate for each product that is assigned an ad-valorem antidumping duty. The effective antidumping rate is calculated as follows:

$$
\text { Rate }_{g t}=\sum_{c} S H A R E_{c, g, t-1} * A V D_{c, g, t}
$$

where $\operatorname{SHARE}_{c, g, t-1}$ is country c's share of U.S. imports of product g in time t-1 and $A V D_{c, g, t}$ is the ad-valorem duty applied to imports of product g from country c in time t. A country's share is calculated based on imports in time t-1, rather than time t, because antidumping duties often lead to significant reductions in imports from pre-protection levels. Using a pre-protection share, therefore, provides a more accurate representation of a country's importance to U.S. trade.

\section{Research Questions}

\section{A. Do Temporary Tariffs Increase or Decrease Plant-Level Productivity?}

As discussed above, some have argued that temporary protection can increase withinplant productivity by increasing the incentive to invest in new technology. On the other hand, temporary protection is also likely to lead to higher prices and mark-ups. Because an increase in revenue-based productivity that occurs at the time of protection could be caused by either of these phenomena, however, it can be difficult to determine what is driving gains in revenue productivity. Using output data measured in units of quantity, I am able to separate these two effects by calculating both revenue and physical productivity measures. Moreover, I am able to 
directly measure the effects of antidumping duties on plant-level prices and mark-ups. I find that apparent growth in productivity associated with antidumping protection is driven primarily by higher prices and mark-ups, rather than increases in true productivity.

\section{Empirical Strategy}

I examine the effect of temporary protection on plant-level productivity, prices and markups using a difference-in-difference approach. As discussed above, the treatment group is composed of plants producing products that receive antidumping protection. I will consider three control groups, including the termination control group composed of plants that applied for, but did not receive protection and the two matched control groups. The goal of the difference-indifference methodology is to isolate the effect of the treatment—antidumping protection—by eliminating time-invariant differences between the treatment and control group, as well as timespecific effects common to both treatment and control. The difference-in-difference estimator, therefore, measures not simply the change in the dependent variable that occurs following antidumping protection, but rather measures the difference between the changes in the treatment group and the changes in the control group.

Let $T$ be the set of plants producing products that receive antidumping protection and let $C$ be the set of plants in a particular control group. Further, define $I_{g}$ to be the date that the antidumping investigation is initiated for product $g$. I measure the difference-in-difference effect by estimating Equation (3):

(3) $\operatorname{Prod}_{p g t}=\alpha+\beta_{1}$ Treatment $_{p g t} *$ Post $_{p g t}+\gamma_{t}+\delta_{g}+\varepsilon_{p t}$, where

Treatment $_{p g t}=1 \forall p \in T$ and Treatment $_{p g t}=0 \forall p \in C$ 
Post $_{p g t}=1 \forall t>I_{g}, 0$ otherwise ${ }^{21}$

Here, $\operatorname{Prod}_{p g t}$ is productivity-measured in TFP or Labor Productivity-at plant p, which produces product g at time t. Year fixed effects capture any macro-level shocks affecting plants in $T$ and $C$ equally. Similarly, product fixed effects, $\delta_{g}$, capture time-invariant differences between products. Note that Equation (3) contains product-level fixed effects, rather than a more general Treatment dummy used in the most basic difference-in-difference expressions. This specification captures time-invariant differences between producers of different products within $T$ and $C$. This is likely important when dealing with a diverse set of manufacturers from different sectors and industries. Finally, the coefficient $\beta_{1}$ on the interaction term is the coefficient of interest and measures the difference-in-difference effect of antidumping protection on the plant-level outcomes discussed below.

Equation (3) defines protection with a binary variable —any plant that receives any antidumping protection is considered to be equally protected. It seems reasonable to expect, however, that plants' reactions to protection would depend not only on this simple binary classification, but also on the level of protection they receive. That is, plants producing products that receive high ad-valorem duty rates—such as the 259.17 percent antidumping duty rate on Aluminum Sulfate from Venezuela—may respond differently than those producing products that receive low antidumping duty rates, such as the 2.98 percent rate on Collated Roofing Nails from

${ }^{21}$ In general, antidumping protection lasts for ten years or more, meaning that almost every antidumping duty put in place during the sample period considered was still in effect at the end of the period. In 3 of the 198 antidumping investigations considered in this sample, however, antidumping protection began prior to 1992, but ended prior to 1997. 
Taiwan. As these two examples indicate, the variation in duty rates among cases that receive protection is large: the mean is 64 percent and the standard deviation is 60 percent.

I measure the effects of heterogeneity in antidumping rates by augmenting Equation (3) with an additional interaction term:

(4) $\operatorname{Prod}_{p g t}=\alpha+\beta_{1}$ Treatment $_{p g t} *$ Post $_{p g t}+\beta_{2}$ Rate $_{p g t} *$ Post $_{p g t}+\gamma_{t}+\delta_{g}+\varepsilon_{p t}$

Here, Rate $_{p g t}$ is the ad-valorem effective antidumping duty rate on product $g$, which is produced

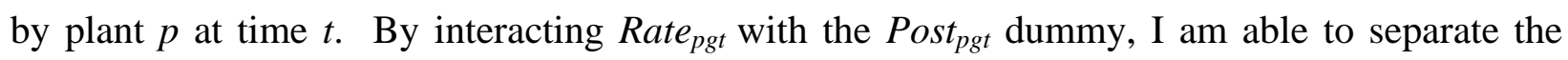
effect of varying rates of protection from the mean response of all plants receiving antidumping protection. $^{22}$

Equations (3) and (4) provide within-product estimates of the effect of antidumping duties on plants. It is important to note, however, that these results do not necessarily reflect the within-plant effect of antidumping duties. Because equations (3) and (4) are estimated on an unbalanced panel, coefficient estimates could reflect changes in mean plant-level productivity due to entry in exit. In order to estimate the within-plant effect of antidumping duties, I reestimate equations (3) and (4) with plant fixed effects for the balanced subsample of plants producing in all three census years. These estimates provide both a useful robustness check for the within product-group estimates, as well an explicit estimate of the within-plant effects of antidumping duties.

\footnotetext{
22 The Treatment binary variable is redundant in this specification because all treated plants have effective duty rates greater than zero. Control plants have effective duty rates that are equal to zero.
} 
Lastly, I will employ the difference-in-difference framework in equations (3) and (4) to examine the effect of antidumping duties on plant-level prices, as well as mark-ups over average total cost. Prices are defined as follows:

$$
P_{p g t}=\frac{T V S_{p g t}}{Q_{p g t}}
$$

where TVS is a plant's total value of shipments and $Q$ is the total quantity of units shipped. Plant-level mark-ups over average total cost are defined as:

$$
\text { PATC }_{p g t}=\frac{P_{p g t}}{A T C_{p g t}}
$$

where $A T C_{p g t}=\frac{\text { Wages }_{p g t}+C M_{p g t}+R T A E_{p g t}}{Q_{p g t}}$

Here, Wages are the wages paid to production workers, $C M$ is the cost of materials and $R T A E$ is real total value of assets, or capital.

\section{$\underline{\text { Results }}$}

\section{Revenue Productivity}

I do find that antidumping protection is associated with increases in revenue productivity of 5 to 8 percent, as shown in Table $5 .^{23}$ The first two columns of Table 5 report the results for equation (3) with TFP and labor productivity and the next two report results for the same specification, with state fixed effects. The final four columns of Table 5 report results from estimation of equation (4), which includes the interaction term accounting for variation in the effective antidumping duty rate. I continue to find a positive and significant relationship

23 Tables 5 and 6 report results based on the termination control group of plants producing products that applied for, but were turned down for protection. 
between antidumping protection and revenue productivity when the effective duty rate is included in the specification, although the rate term is not significant.

In Table 6, I report the equivalent results when estimating equations 3 and 4 with plant fixed effects on the balanced subsample. As discussed above, these within-plant estimates are unaffected by changes in the composition of plants in the product-group caused by entry and exit. The results are consistent with those obtained with product fixed effects, with protected plants exhibiting increases in plant-level productivity of 3 to 6 percent. In sum, the estimates reported in Tables 5 and 6 appear to support the argument that antidumping duties can bring about increases in plant-level productivity. These results are also robust to consideration of the two matched control groups, as can be seen in Tables $5 \mathrm{a}$ and $6 \mathrm{a}^{24}$

\section{Physical Productivity}

As described above, the use of revenue-based productivity measures can yield misleading results in situations where prices and mark-ups may also be changing concomitantly. In particular, because the imposition of antidumping duties likely allows domestic producers to increase prices and mark-ups, revenue productivity measures will overstate any potential productivity gains associated with antidumping protection. Because the CMF contains output data measured in units of quantity for a subset of products, I am able to calculate measures of physical productivity that are unaffected by changes in prices and mark-ups.

\footnotetext{
${ }^{24}$ The increase in revenue productivity associated with antidumping protection—as measured by the binary protection variable-is a robust result in this analysis. It is somewhat surprising, however, that revenue productivity appears to be essentially unaffected by changes in the antidumping duty rate. As will be seen in results below, however, this lack of responsiveness appears to be due to decreases in physical productivity associated with higher antidumping duty rates being offset by increases in prices and mark-ups.
} 
The effect of antidumping duties on plant-level productivity is starkly different when output is measured in units of quantity, rather than revenue. As reported in Table 7, antidumping duties are actually associated with a decrease in physical productivity among the set of plants reporting quantity data. In fact, physical productivity actually falls by a greater amount as the effective duty rate protecting the plant increases. This effect persists when estimating the difference-in-difference specification with plant fixed effects on the balanced subsample, as shown in Table 8. Tables 7a and 8a confirm that these results are robust to consideration of the two matched control groups, as well.

Bernard, Redding and Schott (2006) provides a plausible reason that plant-level productivity may fall in the treatment group, relative to the control group. In this model, tariff protection allows firms to continue producing low-productivity products that they would have otherwise stopped producing. Indeed—as will be discussed in more detail below—I do find that protected plants are less likely to drop investigated products than unprotected plants. This means that while plants in the control group focus on their "core competencies" and produce their highest-productivity products, plants in the treatment group are able to continue producing lowproductivity products. As a result, within-plant productivity increases more in the control group than in the treatment group.

A word of warning in terms of interpreting these results is necessary here. It would be inappropriate based on these results to claim that antidumping duties, in general, decrease plantlevel physical productivity. It is true that antidumping duties were associated with a decline in productivity among the set of plants reporting output data in units of quantity. However, this group is not necessarily representative of the full set of plants subject to antidumping protection. First, as can be seen in Table 3, the distribution of plants across 2-digit SIC sectors is somewhat 
different for the set of plants reporting quantity data, than for the overall sample. Second, when I examine the effect of antidumping protection on the revenue productivity of the subset of plants reporting output in units of quantity, I find that revenue productivity was unaffected by antidumping protection. This contrasts with the increase in revenue productivity associated with antidumping protection in the full sample. Nonetheless the fact that plants in this sub-sample experienced a zero effect of antidumping protection on revenue productivity and a large and highly significant decrease in physical productivity suggests that increases in prices and markups are affecting results based on revenue productivity. ${ }^{25}$

\section{$\underline{\text { Prices and Mark-Ups }}$}

The disparity between results showing the effect of antidumping protection on revenue versus physical productivity suggests that increases in prices and mark-ups are playing a role in the apparent increase in revenue productivity. I use the same difference-in-difference specifications from the productivity analysis to examine the effects of antidumping duties on the measures of prices and mark-ups over average total cost described above.

As reported in Table 9, I find that antidumping duties are associated with price increases of 27 to 36 percent. Moreover, these pricing changes are sensitive to the effective duty rate a plant experiences—-the higher the effective duty rate, the higher the prices charged by the plant. These results hold for both within-product-group and within-plant estimators. Table 10 reports the effects of antidumping protection on mark-ups over average total cost. I find that

${ }^{25}$ An alternative explanation is that plants receiving antidumping protection increase the quality of the products they produce. This seems unlikely, given that the products for which the Census Bureau collects quantity data tend to be commodities, with little room for quality improvement. Nonetheless, exploration of the effect of antidumping duties on product-quality will be an interesting aspect of my future research. 
antidumping duties increase mark-ups over average total cost by 7 percent. Moreover, the magnitude of the mark-ups over average total cost increases as the effective duty rate increases in the within-product estimates. The relationship between the effective duty rate and the level of mark-ups does not hold in the within-plant specifications, however. These results are robust to consideration of the two matched control groups, as can be seen in Tables 9a and 10a.

\section{B. Do Temporary Tariffs Discourage Product-Dropping?}

Bernard, Redding and Schott (2006) shows that reductions in trade barriers can increase firm or plant-level productivity by inducing firms to drop their least productive products, while expanding output of their most productive products. Moreover, product-dropping can yield increases in aggregate productivity — as defined below-as the least productive plants drop products. In fact, I do find that antidumping protection decreases the probability of dropping investigated products.

\section{Empirical Strategy}

The effect of antidumping duties on the probability of dropping products is investigated using a difference-in-difference specification similar to that employed to study changes in plantlevel productivity, prices and mark-ups. By comparing the probability of product-dropping among protected plants to the unprotected plants in the three control groups, I am able to estimate the effect of antidumping duties on product-dropping.

An important difference between this product-switching analysis and the plant-level productivity regressions described above is that the product-switching data are defined at the plant-product-level. This means that I have dropped the restriction that each plant is assigned to a particular treatment or control product. In doing so, I am able to consider the full set of products that are involved in antidumping investigations. I employ a linear probability model, to 
allow for the inclusion of fixed effects and clustering of standard errors and estimate the following two equations:

(5) Drop $_{p g t}^{i}=\alpha+\beta_{1}$ Treatment ${ }_{p g t}^{i} *$ Post $_{p g t}^{i}+\beta_{2}{ }^{\prime} X_{p g t}^{i}+\gamma_{t}+\delta_{g}+\varepsilon_{p g t}^{i}$

(6) Drop $_{p g t}^{i}=\alpha+\beta_{1}$ Treatment ${ }_{p g t}^{i} *$ Post $_{p g t}^{i}+\beta_{2}$ Post $_{p g t}^{i} *$ Rate $_{p g t}^{i}+\beta_{3}^{\prime} X_{p g t}^{i}+\gamma_{t}+\delta_{g}+\varepsilon_{p g t}^{i}$

Drop is a binary variable that equals 1 if product $\mathrm{g}$ is produced by plant $\mathrm{p}$ at time $\mathrm{t}$, but not time $\mathrm{t}+5 . \quad X$ is a matrix of plant-product-level variables found to be determinants of product-dropping in Bernard, Redding and Schott (2008), namely the product-level value of shipments and the number of years a product has been produced (tenure). The superscript i denotes that the data are at the plant-product level. To be clear, the variable Drop only takes into account productdropping by continuing plants. Exiting plants are not considered product-droppers.

\section{Results}

I find that plants are 6 percent less likely to drop protected products than they are to drop unprotected products, as reported in Table 11. Moreover, this product-switching behavior is sensitive to the value of the effective duty rate applied to a product. I find that the probability of dropping a protected product decreases as the effective duty rate assigned to that product increases. In the product-dropping regression, the results are robust to the inclusion of productlevel shipments and product tenure, which are both negative and significant, as expected. These results make clear that more plants produce a given protected product than would be the case if the product was unprotected. They are also robust to consideration of the two matched control groups, as can be seen in Tables $11 \mathrm{~A}$ and $11 \mathrm{~B}$.

This reduction in product-switching brought about by antidumping duties has implications for both plant-level and aggregate productivity. At the plant level, Bernard, 
Redding and Schott (2006) suggests that a reduction in product-dropping resulting from trade protection will lower productivity, relative to unprotected plants. While unprotected plants drop their least productive products to focus on their highest-productivity product-lines, protected plants continue to produce the protected product, resulting in lower relative productivity. A reduction in product-dropping among protected plants can also decrease aggregate productivity growth. In unprotected product-groups, the least productive producers will either exit completely, or drop the unprotected product. In the protected product groups, however, these low-productivity plants are able to continue producing, resulting in lower aggregate productivity relative to the control group.

\section{Do Temporary Tariffs Discourage Plant-Level Exit?}

It is a well-known result that trade protection can slow aggregate productivity growth by preventing the exit of low-productivity plants and firms that would otherwise cease to operate. I examine this question by comparing the probability of plant-level exit in the treatment group of protected plants to that in the control group. I find that antidumping duties do not affect the probability of exit. Plants that are denied protection by the government are no more likely to exit than those that receive antidumping duties.

\section{Empirical Strategy}

I define a plant as exiting in year $\mathrm{t}$ if it appears in the CMF in year $t$, but not in year $t+5$. To be clear, a plant that halts production of the investigated product between year $t$ and year $t+5$, but continues to operate, is not counted as an exit. A binary exit variable is defined in this way for the years 1987 and 1992. The exit variable is missing in 1997 due to a change in productclassification system that makes it difficult to track plant survival from 1997 to 2002. 
I estimate the relationship between antidumping protection and the probability of exit using a difference-in-difference framework identical to the specification used to study changes in product-dropping above. As in the analysis of product-dropping, I employ a linear probability model, to allow for the inclusion of fixed effects and clustering of standard errors:

(7) Exit $_{p g t}=\alpha+\beta_{1}$ Treatment $_{p g t} *$ Post $_{p g t}+\gamma_{t}+\delta_{g}+\varepsilon_{p t}$

The binary dependent variable, Exit was described above. The coefficient $\beta_{1}$ is the primary parameter of interest and estimates the effect of receiving antidumping protection on the probability of exit. As in Equation (3), year and product-group fixed effects are included. Estimates with robust standard errors and clustering at the product-group level are reported in Table 12.

Next, I expand Equation (7) to include plant-level variables that have been found to be important determinants of exit in the large empirical literature on the effects of changes in trade costs on exit. Using determinants of exit from Bernard, Jensen and Schott (2006), I estimate Equation (8):

(8) Exit $_{p g t}=\alpha+\beta_{1}$ Treatment $_{p g t} *$ Post $_{p g t}+\beta^{\prime} X_{p g t}+\gamma_{t}+\delta_{g}+\varepsilon_{p t}$

where $\mathrm{X}$ is a matrix of plant-level variables including log of total employment, plant age, log of capital-labor ratio, log of average wage and indicators for whether the plant is a multi-product plant, or a part of a multi-unit firm. Lastly, I re-estimate Equations (7) and (8) with the Rate*Post interaction variable used to estimate the effect of variation in the effective antidumping duty rate.

Results 
Results are reported in Table 12. While I do find in one specification that higher effective duty rates decrease the probability of exit, the result is not robust. In particular, it disappears when the additional control variables commonly used in analyses of exit are included. Moreover, the magnitude of the coefficient is small. A one percent increase in the effective duty rate decreases the probability of exit by only 0.3 percent. It appears, therefore, that plants that are turned down for protection are no less likely to exit than those receiving protection. Combined with the product-dropping result described above, this suggests that U.S. manufacturers are flexible and dynamic in the face of changes in trade policy. Rather than exiting, they react to being turned down for antidumping duties by dropping the unprotected product and shifting resources to other, potentially higher-productivity products. There is also no effect of antidumping protection on the probability of exit when considering the two matched control groups, as can be seen in Tables 12A and 12B.

\section{Do Temporary Tariffs Decrease Output Rationalization and Aggregate}

\section{Productivity?}

A number of theoretical models including Melitz (2003) and Bernard, Redding and Schott (2006) predict that tariff increases allow for the continued operation of low-productivity firms that might otherwise stop production. If antidumping duties create a similar situation, we should expect the level of output rationalization to increase in the control group relative to the treatment group. Indeed, I do find that the level of output rationalization rises in the control group and falls among the protected plants in the treatment group.

\section{Empirical Strategy}

I have already shown that antidumping duties allow plants that would have otherwise dropped the investigated product to continue producing. If these plants that would have 
otherwise dropped the product are also low-productivity plants, antidumping duties may have a negative effect on output rationalization and aggregate productivity growth. To compare the productivity of product-dropping plants to non-droppers, I regress plant-level productivity on a binary variable that equals one in time $\mathrm{t}$ if plant $\mathrm{p}$ dropped an investigated product between time $\mathrm{t}$ and time $\mathrm{t}+5$ :

(12) $\operatorname{Prod}_{p g t}=\alpha+\beta_{1}$ Drop $_{p g t}+\gamma_{t}+\delta_{g}+\varepsilon_{p t}$

Next, I examine the level of output rationalization directly by decomposing aggregate productivity as in Olley and Pakes (1996), Pavcnik (2002) and Fernandes (2007). This procedure decomposes growth in aggregate productivity into two components, shown below:

(13) $W_{g t}=\sum_{p} s_{p g t} T F P_{p g t}=T F P_{t g}^{\text {mean }}+\left(s_{p g t}-s_{g t}^{\text {mean }}\right)\left(T F P_{p g t}-T F P_{g t}^{\text {mean }}\right)$

The first term of the final expression represents mean plant-level productivity at time t. The second term is a covariance-like variable representing the degree to which greater output is produced by higher-productivity plants. $s_{p g t}$ denotes the share of plant $p$ 's output in the total output of product-group $g$ at time $t$, while $s_{g t}^{\text {mean }}$ is the mean output share of plants producing product $g$ at time $t$. Similarly, $T F P_{p g t}$ and $T F P_{g t}^{\text {mean }}$ represent the revenue total factor productivity of plant $p$ and the mean TFP of plants in product-group $g$, respectively. When plants with aboveaverage TFP also capture an above-average market share, the covariance term increases, indicating a higher level of output rationalization.

The covariance term measuring the degree of output rationalization will be the primary variable of interest. Ideally, I would simply examine the effects of antidumping duties on aggregate productivity, $W_{g t}$ directly. A number of data problems would make this comparison 
unreliable, however. First, as mentioned above, the use of revenue-based aggregate productivity measures would overstate productivity gains among protected product-groups, since I have shown that protected plants respond to temporary protection by increasing prices. Moreover, quantity-based productivity measures are not useful in settings where analysis is taking place at the product-group level or higher, since quantity data are only available for producers of a limited set of products.

The use of revenue-based productivity measures is less problematic for analyzing output rationalization. Assuming that prices increase uniformly among all producers of a given product once it receives protection, the covariance term will still accurately reflect the degree of output rationalization within a product group. After calculating aggregate productivity, mean plantlevel productivity and the output rationalization term at the product-group-level, I report their output-weighted means by year, treatment group and a dummy variable indicating whether the antidumping investigation for product $\mathrm{g}$ has already taken place. The results of the decomposition described are reported in Table 14.

\section{Results}

First, I find that plants that drop the investigated product have lower productivities than non-dropping plants, as reported in Table 13. As a result, the reduction in product-dropping by low-productivity plants caused by antidumping duties may contribute to a decrease in output rationalization and aggregate productivity growth among protected product-groups.

Indeed, I do find that antidumping protection decreased the level of output rationalization in the treatment group, while output rationalization grew in the control group. As reported in Table 14, the treatment group of plants that ultimately receive protection starts with a level of output rationalization in 1987 that is higher than the control group. As time progresses and 
protection takes effect, however, output rationalization falls in the treatment group-likely due to continued operation by low-productivity plants that would have otherwise dropped the investigated product—and rises in the control group. By 1997, the control group has overtaken the treatment group in terms of output rationalization. By preventing the reallocation of resources that takes place as a result of trade liberalization, therefore, antidumping duties contribute to a reduction in aggregate productivity.

\section{Section 6: Conclusions}

Antidumping duties have become one of the primary forms of trade protection worldwide, and the large magnitudes of the duties imposed can dramatically alter trade flows. Yet despite the growing importance of antidumping duties to international trade, there is little understanding of their effects at the micro level. In addition to increasing our understanding of an important trade policy, the study of antidumping duties can also provide new insights into some of the best-known results in the literature examining the heterogeneous responses of firms to trade liberalization.

Using a difference-in-difference framework, I compare outcomes at plants in the treatment group that receives protection to those in the three control groups that did not. I find that apparent increases in revenue productivity associated with antidumping protection are driven primarily by increases in prices and mark-ups. Physical productivity actually falls among the protected plants reporting output data in units of quantity. Protected plants are also less likely to drop protected products, although they are no less likely exit. Because antidumping protection allows for the continued operation of low-productivity plants that might have otherwise dropped the protected product, antidumping duties decrease the level of output rationalization, with lowproductivity plants expanding their market shares. 
The results have several implications. First, for empirical researchers, the results underscore the importance of differentiating between changes in revenue productivity—which may be driven by increases in prices and mark-ups-and changes in physical productivity. Separating these two effects is particularly important in situations where changes in productivity may be taking place concomitantly with changes in prices, as is the case with antidumping duties. Second, for theoretical researchers, the results underscore the importance of thinking of plants and firms as producers of multiple products. While antidumping duties had no effect on the probability of plant exit, they had a clear impact on plants' product mix. And finally, for policy-makers, the results suggest that antidumping protection does not offer a free lunch in the form of higher plant-level productivity. Offering antidumping protection comes at a cost that is incurred by consumers, in the form of higher prices. 


\section{References}

Amiti, Mary and Jozef Konings (2007), “Trade Liberalization, Intermediate Inputs and Productivity: Evidence from Indonesia,” American Economic Review, 97, pp. 1611-1638.

Aw, B.Y., Chung, S. and Mark Roberts (2000), "Productivity and Turnover in the Export Market: Micro-Level Evidence from Korea and Taiwan (China),” World Bank Economic Review, 14, pp. 65-90

Bartelsman, Eric J., Randy A. Becker and Wayne B. Gray (2000) “NBER-CES Manufacturing Industry Database,” NBER Technical Working Paper 205.

Bernard, Andrew and J. Bradford Jensen (1999), “Exceptional Exporter Performance: Cause, Effect, or Both?,” Journal of International Economics, 47, pp. 1-25.

Bernard, Andrew, Jonathan Eaton, J. Bradford Jensen and Samuel Kortum (2003), "Plants and Productivity in International Trade,” American Economic Review, 93, pp. 1268-1290.

Bernard, Andrew, J. Bradford Jensen and Peter Schott (2006), “Trade Costs, Firms and Productivity,” Journal of Monetary Economics, 53, pp. 917-937.

Bernard, Andrew, Stephen Redding and Peter Schott (2006), “Multi-Product Firms and Trade Liberalization,” mimeo.

Bernard, Andrew, Stephen Redding and Peter Schott (2009), "Multi-Product Firms and ProductSwitching,” American Economic Review, forthcoming.

Blonigen, Bruce and Jee-Hyeong Park (2004), “Dynamic Pricing in the Presence of Antidumping Policy: Theory and Evidence,” American Economic Review, 94, pp.134-154.

Bown, Chad (2007), “Global Antidumping Database 3.0,” mimeo. 
Caves, Douglas W., Laurits R. Christensen and W. Erwin Diewert (1982), “The Economic Theory of Index Numbers and the Measurement of Input, Output and Productivity,” Econometrica, 50(6), pp. 1393-1414.

Crowley, Meredith (2006), “Do Antidumping Duties and Safeguard Tariffs Open or Close Technology Gaps?,” Journal of International Economics, 68, pp. 469-484.

Fernandes, Ana (2007), “Trade Policy, Trade Volumes and Plant-Level Productivity in Colombian Manufacturing Industries,” Journal of International Economics, 71(1), pp. $52-71$.

Feenstra, Robert, John Romalis and Peter Schott (2002), “U.S. Imports, Exports and Tariff Data,” NBER Working Paper \# 9387.

Goh, A.-T. (2000), “Opportunity Cost, Trade Policies and the Efficiency of Firms,” Journal of Development Economics, 62, pp. 363-383.

Konings, Jozef and Hylke Vandenbussche (2008), "Heterogeneous Responses of Firms to Trade Protection,” Journal of International Economics, 76, pp. 371-383.

Konings, Jozef and Hylke Vandenbussche (2005), “Antidumping Protection and Markups of Domestic Firms: Evidence from Firm Level Data,” Journal of International Economics, 65, pp. 151-165.

Levinsohn, James and Amil Petrin (2003), "Estimating Production Functions Using Intermediates to Control for Unobservables,” Review of Economic Studies, 70, pp. 317341.

Matsuyama, Kiminori (1990), “Perfect Equilibria in a Trade Liberalization Game,” American Economic Review, 80(3), pp. 480-492. 
Melitz, Marc J. (2003), “The Impact of Trade on Aggregate Industry Productivity and IntraIndustry Reallocations.” Econometrica, 71(6), pp. 1695-725.

Miyagiwa, Kaz and Yuka Ohno (1995), “Closing the Technology Gap Under Protection,” American Economic Review, 85(4), pp. 755-770.

Miyagiwa, Kaz and Yuka Ohno (1999), "Credibility of Protection and Incentives to Innovate,” International Economic Review, 40(1), pp. 143-163.

Pavcnik, Nina (2002), “Trade Liberalization, Exit and Productivity Improvements: Evidence from Chilean Plants.” Review of Economic Studies, 69(1), pp. 245-76.

Pierce, Justin (2008), “Trade Liberalization, Productivity and Input Variety: Evidence from Colombian Plants,” Georgetown University, mimeo, 2009.

Serti, Francesco and Chiara Tomasi (2007), "Self Selection and Post-Entry Effects of Exports. Evidence from Italian Firms,” mimeo.

United States International Trade Commission (2006), "Import Injury Investigations: Case Statistics: FY 1980-2005.”

Van Biesebroeck, Johannes (2004), “Robustness of Productivity Estimates,” National Bureau of Economic Research Working Paper 10303. 
Table 1: Antidumping Investigations by HTS Chapter, 1988-1996

\begin{tabular}{c|l|c} 
HTS2 & Description & Investigations \\
\hline 73 & Articles of Iron and Steel & 27 \\
72 & Iron and Steel & 20 \\
84 & Machinery & 16 \\
28 & Inorganic Chemicals & 14 \\
85 & Electrical Machinery & 13 \\
29 & Organic Chemicals & 12 \\
87 & Transportation Vehicles and Parts & 11 \\
90 & Precision Instruments and Apparatus & 8 \\
39 & Plastics and Articles Thereof & 6 \\
25 & Plastering, Lime and Cement & 5 \\
81 & Other Base Metals & 5 \\
30 & Pharmaceutical Products & 4 \\
40 & Rubber and Articles Thereof & 4 \\
56 & Certain Textiles & 4 \\
83 & Misc. Articles of Base Metal & 4 \\
\hline Other & & 45 \\
\hline Total & & 198
\end{tabular}

Notes: This table displays the number of antidumping investigations by 2-digit Harmonized Tariff System Category. Investigations involving products in more than one 2-digit HTS category are counted in each relevant category. 
Table 2: All Antidumping Cases, by Outcome and SIC2

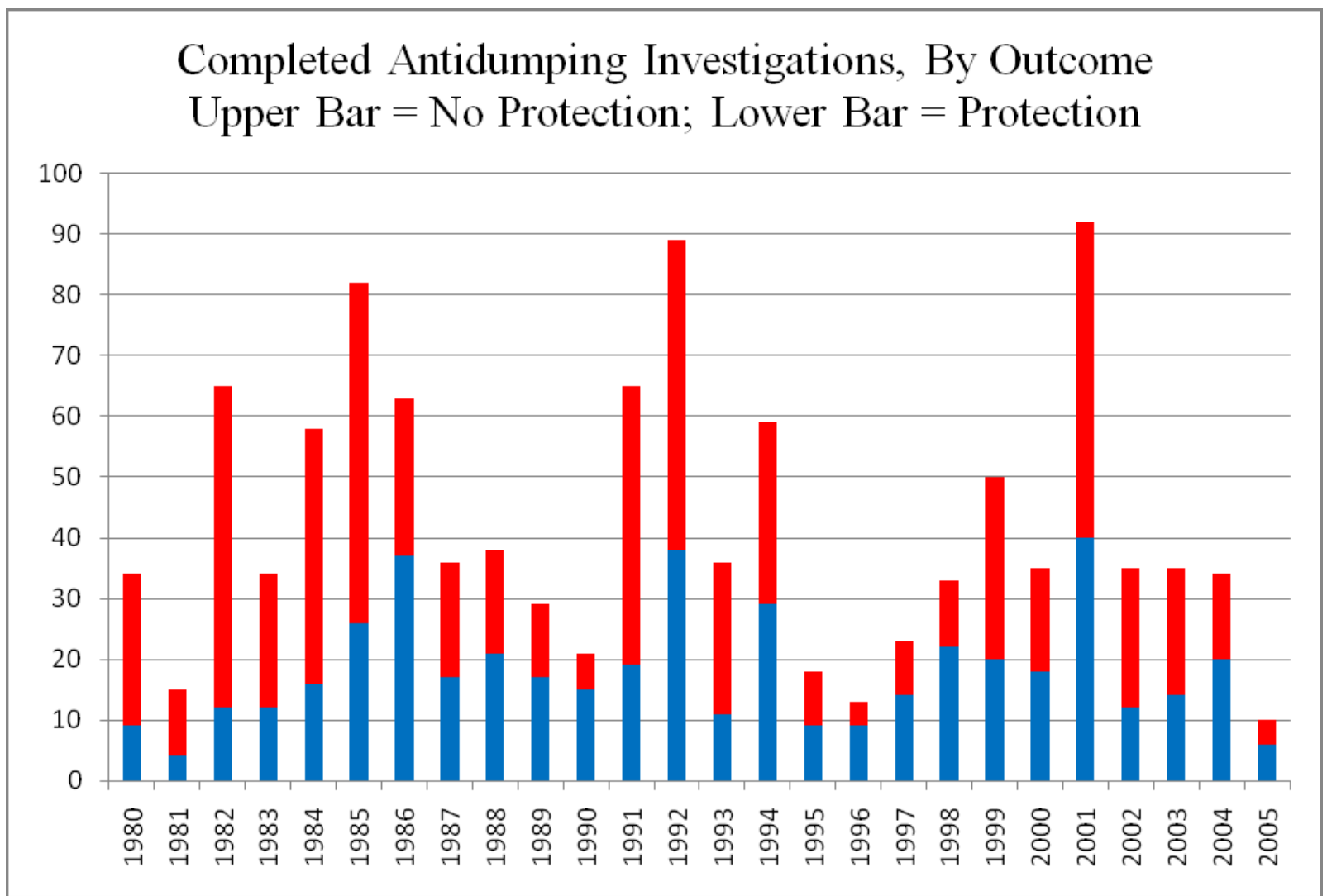


Table 3: Plant-Level Observations, by SIC2

\begin{tabular}{l|c|c|c|c|c|c|c|c} 
& \multicolumn{5}{|c|}{ Total Observations } & \multicolumn{3}{c}{ Observations With Quantity } \\
\hline SIC2 Description & SIC2 & Control & Treatment & Total & SIC2 & Control & Treatment & Total \\
\hline Food and Kindred Spirits & 20 & 163 & 1,462 & 1,625 & 20 & 132 & 1,096 & 1,228 \\
Textile Mill Products & 22 & 1,061 & 891 & 1,952 & 22 & 757 & 415 & 1,172 \\
Apparel & 23 & 8,283 & 1,725 & 10,008 & 23 & 928 & 532 & 1,460 \\
Paper Products & 26 & 2,602 & 0 & 2,602 & 26 & 1,065 & 0 & 1,065 \\
Chemical Products & 28 & 815 & 3,566 & 4,381 & 28 & 77 & 652 & 729 \\
Rubber Products & 30 & 13,681 & 2,996 & 16,677 & 30 & 170 & 14 & 184 \\
Leather Products & 32 & 2,081 & 582 & 2,663 & 32 & 451 & 396 & 847 \\
Primary Metals & 33 & 468 & 3,266 & 3,734 & 33 & $*$ & 1,971 & $*$ \\
Fabricated Metals & 34 & 13,244 & 4,318 & 17,562 & 34 & 1,038 & 500 & 1,538 \\
Industrial Machinery & 35 & 3,884 & 16,066 & 19,950 & 35 & 180 & 314 & 494 \\
Electronic Machinery & 36 & 650 & 7,540 & 8,190 & 36 & 91 & 35 & 126 \\
Transport Equipment & 37 & 2,869 & 889 & 3,758 & 37 & 723 & $*$ & $*$ \\
Measuring Instruments & 38 & 75 & 3,071 & 3,146 & 38 & 25 & $*$ & $*$ \\
Misc. Manufacturing & 39 & 0 & 413 & 413 & 39 & 0 & 88 & 88
\end{tabular}

Notes: This table reports the number of plant-level observations in the treatment group (applied and received protection) and control group (applied but did not receive protection), by 2-digit SIC (1987) category. In addition, the table shows the number of plant-level observations where output data were reported in units of quantity by treatment status and SIC2. An asterisk (*) denotes a cell that was suppressed to prevent the disclosure of confidential data. 
Table 4: Summary Statistics by Treatment Group, Year

\begin{tabular}{c|c|c|c|c|c|c|c|c} 
Year & Treatment & $\begin{array}{c}\text { Total } \\
\text { Sales }\end{array}$ & $\begin{array}{c}\text { No. } \\
\text { Employees }\end{array}$ & $\begin{array}{c}\text { Capital } \\
\text { Intensity }\end{array}$ & $\begin{array}{c}\text { No. } \\
\text { Plants }\end{array}$ & $\begin{array}{c}\text { Qty. } \\
\text { Share }\end{array}$ & $\begin{array}{c}\text { Treatment } \\
\text { Share }\end{array}$ & $\begin{array}{c}\text { Effective } \\
\text { AD Rate }\end{array}$ \\
\hline 1987 & 0 & 23,596 & 142 & 41 & 15,007 & $93 \%$ & $70 \%$ & \\
1987 & 1 & 23,437 & 165 & 53 & 14,598 & $93 \%$ & $68 \%$ & $14 \%$ \\
1992 & 0 & 26,250 & 122 & 46 & 17,092 & $93 \%$ & $69 \%$ & \\
1992 & 1 & 28,703 & 149 & 56 & 15,588 & $92 \%$ & $67 \%$ & $13 \%$ \\
1997 & 0 & 33,234 & 119 & 52 & 17,778 & $93 \%$ & $69 \%$ & \\
1997 & 1 & 38,025 & 146 & 73 & 16,599 & $92 \%$ & $67 \%$ & $13 \%$ \\
& & & & & & & & \\
1987 & & & & & & & \\
1987 & 1 & 0.14 & 4.63 & 0.30 & 5.65 & & \\
1992 & 0 & 0.11 & 4.72 & -0.02 & 5.48 & & & \\
1992 & 1 & 0.19 & 4.72 & -0.06 & 5.43 & & & \\
1997 & 0 & 0.11 & 4.80 & 0.26 & 5.87 & & & \\
1997 & 1 & 0.29 & 4.89 & -0.12 & 5.45 & &
\end{tabular}

Notes: This table reports summary statistics by year and treatment status. A treatment of zero (0) denotes the control group and a treatment of one (1) denotes the treatment group. Capital intensity is the book value of capital divided by the number of employees. 
Table 5: Antidumping Duties and Revenue Productivity - Within Product-Group Estimators Termination Control Group

\begin{tabular}{l|c|c|c|c|c|c|c|c} 
& TFP & LP & TFP & LP & TFP & LP & TFP & LP \\
\hline Treatment*Post & $0.06^{* *}$ & $0.05^{* *}$ & $0.06^{* *}$ & $0.05^{* *}$ & $0.08^{* *}$ & $0.06^{* *}$ & $0.08^{* *}$ & $0.06^{* *}$ \\
& 0.03 & 0.02 & 0.03 & 0.02 & 0.03 & 0.02 & 0.03 & 0.02 \\
Post*Rate & & & & & -0.001 & -0.001 & -0.001 & -0.001 \\
& & & & & 0.002 & 0.001 & 0.002 & 0.001 \\
Year FE & Yes & Yes & Yes & Yes & Yes & Yes & Yes & Yes \\
Product FE & Yes & Yes & Yes & Yes & Yes & Yes & Yes & Yes \\
State FE & No & No & Yes & Yes & No & No & Yes & Yes \\
Observations & 96,662 & 96,662 & 96,662 & 96,662 & 96,662 & 96,662 & 96,662 & 96,662 \\
R-Squared & 0.666 & 0.309 & 0.668 & 0.313 & 0.666 & 0.39 & 0.668 & 0.313
\end{tabular}

Notes: This table summarizes OLS regression coefficients of plant-level total factor productivity (TFP) and labor productivity (LP) on the difference-in-difference interaction term "Treatment*Post" and the effective duty rate interaction term "Post*Rate." Robust standard errors are reported below each coefficient after adjustment for clustering at the product-level. $\quad * * *, * *$ and $*$ represent statistical significance at the $1 \%, 5 \%$ and $10 \%$ levels, respectively.

Table 5A: Antidumping Duties and Revenue Productivity - Within Product-Group Estimators Matched Control Groups

\begin{tabular}{l|c|c|c|c|c|c|c|c} 
& \multicolumn{4}{c|}{ Matched Control Group 1 } & \multicolumn{4}{c}{ Matched Control Group 2} \\
& TFP & LP & TFP & LP & TFP & LP & TFP & LP \\
\hline Treatment*Post & $0.10^{* * *}$ & $0.10^{* * *}$ & $0.11^{* * *}$ & $0.11^{* * *}$ & $0.08^{* *}$ & $0.06 * * *$ & $0.10^{* * *}$ & $0.07 * * *$ \\
& 0.04 & 0.02 & 0.04 & 0.03 & 0.03 & 0.02 & 0.03 & 0.02 \\
Post*Rate & & & -0.001 & -0.001 & & & -0.0011 & -0.001 \\
& & & 0.003 & 0.002 & & & 0.0022 & 0.001 \\
Year FE & Yes & Yes & Yes & Yes & Yes & Yes & Yes & Yes \\
Product FE & Yes & Yes & Yes & Yes & Yes & Yes & Yes & Yes \\
Observations & 131,730 & 131,730 & 131,730 & 131,730 & 84,857 & 84,857 & 84,857 & 84,857 \\
R-Squared & 0.797 & 0.418 & 0.797 & 0.418 & 0.66 & 0.317 & 0.66 & 0.317
\end{tabular}

Notes: This table summarizes OLS regression coefficients of plant-level total factor productivity (TFP) and labor productivity (LP) on the difference-in-difference interaction term "Treatment*Post" and the effective duty rate interaction term "Post*Rate." Robust standard errors are reported below each coefficient after adjustment for clustering at the product-level. ***, ** and $*$ represent statistical significance at the $1 \%, 5 \%$ and $10 \%$ levels, respectively. 
Table 6: Antidumping Duties and Revenue Productivity - Within Plant Estimators Termination Control Group

\begin{tabular}{l|c|c|c|c} 
& TFP & LP & TFP & LP \\
\hline Treatment*Post & $0.0487^{* * *}$ & $0.0256^{* * *}$ & $0.0632^{* * *}$ & $0.0312^{* * *}$ \\
& 0.0104 & 0.0082 & 0.0124 & 0.0098 \\
Post*Rate & & & $-0.0011^{* *}$ & -0.0004 \\
& & & 0.0005 & 0.0004 \\
Year FE & Yes & Yes & Yes & Yes \\
Plant FE & Yes & Yes & Yes & Yes \\
Observations & 27,699 & 27,699 & 27,699 & 27,699 \\
R-Squared & 0.909 & 0.874 & 0.99 & 0.874
\end{tabular}

Notes: This table summarizes OLS regression coefficients of plant-level total factor productivity (TFP) and labor productivity (LP) on the difference-in-difference interaction term "Treatment*Post" and the effective duty rate interaction term "Post*Rate." Robust standard errors are reported below each coefficient after adjustment for clustering at the plant-level. ***, ** and * represent statistical significance at the $1 \%, 5 \%$ and $10 \%$ levels, respectively.

Table 6A: Antidumping Duties and Revenue Productivity - Within Plant Estimators Matched Control Groups

\begin{tabular}{l|c|c|c|c|c|c|c|c}
\multicolumn{1}{c|}{} & \multicolumn{4}{c|}{ Matched Control Group 1 } & \multicolumn{4}{c}{ Matched Control Group 2} \\
& TFP & LP & TFP & LP & TFP & LP & TFP & LP \\
\hline \multirow{2}{*}{ Treatment*Post } & $0.08^{* * *}$ & $0.08^{* * *}$ & $0.10^{* * *}$ & $0.09^{* * *}$ & $0.04 * * *$ & $0.02 * *$ & $0.06 * * *$ & $0.03^{* *}$ \\
& 0.001 & 0.01 & 0.01 & 0.01 & 0.01 & 0.008 & 0.01 & 0.01 \\
Post*Rate & & & $-0.004^{* *}$ & -0.0001 & & & $-0.001^{* *}$ & -0.001 \\
& & & 0.001 & 0.0005 & & & 0.005 & 0.0004 \\
Year FE & Yes & Yes & Yes & Yes & Yes & Yes & Yes & Yes \\
Plant FE & Yes & Yes & Yes & Yes & Yes & Yes & Yes & Yes \\
Observations & 40,374 & 40,374 & 40,374 & 40,374 & 24,471 & 24,471 & 24,471 & 24,471 \\
R-Squared & 0.945 & 0.895 & 0.945 & 0.895 & 0.913 & 0.874 & 0.913 & 0.874
\end{tabular}

Notes: This table summarizes OLS regression coefficients of plant-level total factor productivity (TFP) and labor productivity (LP) on the difference-in-difference interaction term "Treatment*Post" and the effective duty rate interaction term "Post*Rate." Robust standard errors are reported below each coefficient after adjustment for clustering at the product-level. $* * *, * *$ and * represent statistical significance at the $1 \%, 5 \%$ and $10 \%$ levels, respectively. 
Table 7: Antidumping Duties and Physical Productivity - Within Product-Group Estimators Termination Control Group

\begin{tabular}{l|c|c|c|c|c|c|c|c} 
& \multicolumn{4}{|c|}{ Physical Productivity Measures } & \multicolumn{3}{c}{ Revenue Productivity Measures } \\
\hline & TFPQ & LPQ & TFPQ & LPQ & TFP & LP & TFP & LP \\
\hline Treatment*Post & $-0.39 *$ & $-0.43^{* *}$ & 0.22 & 0.16 & 0.005 & -0.03 & 0.05 & 0.004 \\
& 0.22 & 0.21 & 0.18 & 0.17 & 0.070 & 0.03 & 0.07 & 0.042 \\
Post*Rate & & & $-0.03^{* * *}$ & $-0.03^{* * *}$ & & & -0.002 & -0.002 \\
& & & 0.005 & 0.005 & & & 0.002 & 0.002 \\
Year FE & Yes & Yes & Yes & Yes & Yes & Yes & Yes & Yes \\
Product FE & Yes & Yes & Yes & Yes & Yes & Yes & Yes & Yes \\
Observations & 11,526 & 11,526 & 11,526 & 11,526 & 11,526 & 11,526 & 11,526 & 11,526 \\
R-Squared & 0.643 & 0.62 & 0.646 & 0.623 & 0.868 & 0.451 & 0.868 & 0.451
\end{tabular}

Notes: This table summarizes OLS regression coefficients of plant-level productivity on the difference-in-difference interaction term "Treatment*Post" and the effective duty rate interaction term "Post*Rate." The first four columns show regression results using measures of physical productivity as the dependent variable, for the subset of plants reporting quantity-based output data. The last four columns show regression results using measures of revenue productivity as the dependent variable, for the same subset of plants. TFPQ denotes physical total-factorproductivity and LPQ denotes physical labor productivity. Robust standard errors are reported below each coefficient after adjustment for clustering at the product-level. $* * *, * *$ and * represent statistical significance at the $1 \%, 5 \%$ and $10 \%$ levels, respectively. 
Table 7A: Antidumping Duties and Physical Productivity - Within Product-Group Estimators Matched Control Groups

\begin{tabular}{l|c|c|c|c|c|c|c|c} 
& \multicolumn{5}{|c|}{ Matched Control Group 1 } & \multicolumn{4}{c}{ Matched Control Group 2 } \\
\hline \multirow{2}{*}{ Treatment*Post } & TFPQ & LPQ & TFPQ & LPQ & TFPQ & LPQ & TFPQ & LPQ \\
\cline { 2 - 9 } & $-0.43^{*}$ & $-0.42^{*}$ & 0.12 & 0.09 & $-0.40^{*}$ & $-0.47 * *$ & 0.22 & 0.12 \\
Post*Rate & 0.26 & 0.23 & 0.22 & 0.21 & 0.24 & 0.21 & 0.19 & 0.18 \\
& & & $-0.03^{* *}$ & $-0.03^{* *}$ & & & $-0.03^{* * *}$ & $-0.03^{* * *}$ \\
Year FE & & 0.01 & 0.01 & & & 0.005 & 0.005 \\
Product FE & Yes & Yes & Yes & Yes & Yes & Yes & Yes & Yes \\
Observations & Yes & Yes & Yes & Yes & Yes & Yes & Yes & Yes \\
R-Squared & 7,220 & 7,220 & 7,220 & 7,220 & 10,086 & 10,086 & 10,086 & 10,086 \\
& 0.647 & 0.612 & 0.651 & 0.616 & 0.639 & 0.611 & 0.643 & 0.614
\end{tabular}

Notes: These tables summarize OLS regression coefficients of plant-level physical productivity on the difference-in-difference interaction term "Treatment*Post" and the effective duty rate interaction term "Post*Rate." TFPQ denotes physical total-factor-productivity and LPQ denotes physical labor productivity. Robust standard errors are reported below each coefficient after adjustment for clustering at the product-level. ***, ** and * represent statistical significance at the $1 \%, 5 \%$ and $10 \%$ levels, respectively. 
Table 8: Antidumping Duties and Physical Productivity - Within Plant Estimators Termination Control Group

\begin{tabular}{|c|c|c|c|c|c|c|c|c|}
\hline & \multicolumn{4}{|c|}{ Physical Productivity Measures } & \multicolumn{4}{|c|}{ Revenue Productivity Measures } \\
\hline & TFPQ & LPQ & TFPQ & LPQ & TFP & LP & TFP & LP \\
\hline Treatment*Post & $-0.29 * *$ & $-0.20 *$ & $0.35^{* *}$ & $0.37 * *$ & 0.01 & 0.03 & 0.07 & 0.01 \\
\hline & 0.11 & 0.11 & 0.16 & 0.15 & 0.03 & 0.03 & 0.04 & 0.04 \\
\hline Post*Rate & & & $-0.04 * * *$ & $-0.03 * * *$ & & & $-0.003^{* *}$ & 0.001 \\
\hline & & & 0.01 & 0.01 & & & 0.002 & 0.001 \\
\hline Year FE & Yes & Yes & Yes & Yes & Yes & Yes & Yes & Yes \\
\hline Plant FE & Yes & Yes & Yes & Yes & Yes & Yes & Yes & Yes \\
\hline Observations & 2,550 & 2,550 & 2,550 & 2,550 & 2,550 & 2,550 & 2,550 & 2,550 \\
\hline R-Squared & 0.896 & 0.904 & 0.91 & 0.98 & 0.899 & 0.906 & 0.899 & 0.906 \\
\hline
\end{tabular}

Notes: These tables summarize OLS regression coefficients of plant-level productivity on the difference-in-difference interaction term "Treatment*Post" and the effective duty rate interaction term "Post*Rate." The first four columns of each table show regression results using measures of physical productivity as the dependent variable, for the subset of plants reporting quantity-based output data. The last four columns show regression results using measures of revenue productivity as the dependent variable, for the same subset of plants. TFPQ denotes physical total-factor-productivity and LPQ denotes physical labor productivity. Robust standard errors are reported below each coefficient after adjustment for clustering at the plant-level. ***, ** and * represent statistical significance at the $1 \%, 5 \%$ and $10 \%$ levels, respectively. 
Table 8A: Antidumping Duties and Physical Productivity - Within Plant Estimators

\section{Matched Control Groups}

\begin{tabular}{l|c|c|c|c|c|c|c|c} 
& \multicolumn{4}{|c|}{ Matched Control Group 1 } & \multicolumn{4}{c}{ Matched Control Group 2 } \\
\hline & TFPQ & LPQ & TFPQ & LPQ & TFPQ & LPQ & TFPQ & LPQ \\
\hline \multirow{2}{*}{ Treatment*Post } & $-0.60^{* * *}$ & $-0.39 * * *$ & 0.02 & 0.17 & $-0.36^{* *}$ & $-0.31^{* *}$ & 0.27 & 0.26 \\
& 0.15 & 0.14 & 0.17 & 0.17 & 0.14 & 0.14 & 0.18 & 0.17 \\
Post*Rate & & & $-0.04^{* * *}$ & $-0.03^{* * *}$ & & & $-0.04^{* * *}$ & $-0.03^{* * *}$ \\
& & & 0.01 & 0.01 & & & 0.01 & 0.01 \\
Year FE & Yes & Yes & Yes & Yes & Yes & Yes & Yes & Yes \\
Plant FE & Yes & Yes & Yes & Yes & Yes & Yes & Yes & Yes \\
Observations & 2,013 & 2,013 & 2,013 & 2,013 & 2,268 & 2,268 & 2,268 & 2,268 \\
R-Squared & 0.911 & 0.919 & 0.917 & 0.923 & 0.911 & 0.919 & 0.917 & 0.924
\end{tabular}

Notes: These tables summarize OLS regression coefficients of plant-level physical productivity on the difference-indifference interaction term "Treatment*Post" and the effective duty rate interaction term "Post*Rate." TFPQ denotes physical total-factor-productivity and LPQ denotes physical labor productivity. Robust standard errors are reported below each coefficient after adjustment for clustering at the product-level. ${ }^{* * *},{ }^{* *}$ and ${ }^{*}$ represent statistical significance at the $1 \%, 5 \%$ and $10 \%$ levels, respectively. 
Table 9: The Effect of Antidumping Duties on Plant-Level Prices Termination Control Group

\begin{tabular}{l|c|c|c|c} 
& Price & Price & Price & Price \\
\hline Treatment*Post & $0.42^{* *}$ & -0.16 & $0.27^{* *}$ & $-0.35^{* *}$ \\
& 0.20 & 0.17 & 0.11 & 0.15 \\
Post*Rate & & $0.03^{* * *}$ & & $0.04 * * *$ \\
& & 0.00 & & 0.01 \\
Year FE & Yes & Yes & Yes & Yes \\
Product FE & Yes & Yes & No & No \\
Plant FE & No & No & Yes & Yes \\
Observations & 11,526 & 11,526 & 2,550 & 2,550 \\
R-Squared & 0.66 & 0.66 & 0.90 & 0.91
\end{tabular}

Table 9A: The Effect of Antidumping Duties on Plant-Level Prices Matched Control Groups

\begin{tabular}{l|c|c|c|c|c|c|c|c} 
& \multicolumn{4}{|c|}{ Matched Control 1 } & \multicolumn{4}{c}{ Matched Control 2} \\
& Price & Price & Price & Price & Price & Price & Price & Price \\
\hline Treatment*Post & $0.38^{*}$ & -0.15 & $0.36 * *$ & -0.24 & $0.44 * *$ & -0.14 & $0.32 * *$ & -0.30 \\
& 0.21 & 0.20 & 0.15 & 0.18 & 0.20 & 0.17 & 0.14 & 0.17 \\
Post*Rate & & $0.03^{* * *}$ & & $0.04 * * *$ & & $0.03 * * *$ & & $0.037 * *$ \\
& & 0.01 & & 0.01 & & 0.00 & & 0.01 \\
Year FE & Yes & Yes & Yes & Yes & Yes & Yes & Yes & Yes \\
Product FE & Yes & Yes & No & No & Yes & Yes & No & No \\
Plant FE & No & No & Yes & Yes & No & No & Yes & Yes \\
Observations & 7,220 & 7,220 & 2,013 & 2,013 & 10,086 & 10,086 & 2,268 & 2,268 \\
R-Squared & 0.63 & 0.63 & 0.90 & 0.91 & 0.63 & 0.64 & 0.91 & 0.91
\end{tabular}

Notes: These tables summarize OLS regression coefficients of plant-level price on the difference-in-difference interaction term "Treatment*Post" and the effective duty rate interaction term "Post*Rate." Robust standard errors are reported below each coefficient after adjustment for clustering at the plant-level. ***, ** and * represent statistical significance at the $1 \%, 5 \%$ and $10 \%$ levels, respectively. Results with plant fixed effects are based on the balanced sub-sample of plants that were active in all three census years. 
Table 10: The Effect of Antidumping Duties on Mark-Ups Termination Control Group

\begin{tabular}{l|c|c|c|c} 
& P/ATC & P/ATC & P/ATC & P/ATC \\
\hline Treatment*Post & $0.06 * *$ & 0.037 & $0.07 * * *$ & 0.048 \\
& 0.024 & 0.029 & 0.024 & 0.032 \\
Post*Rate & & 0.001 & & 0.002 \\
& & 0.001 & & 0.002 \\
Year FE & Yes & Yes & Yes & Yes \\
Product FE & Yes & Yes & No & No \\
Plant FE & No & No & Yes & Yes \\
Observations & 11,526 & 11,526 & 2,550 & 2,550 \\
R-Squared & 0.30 & 0.33 & 0.69 & 0.69
\end{tabular}

Table 10A: The Effect of Antidumping Duties on Mark-Ups Termination Control Group

\begin{tabular}{l|c|c|c|c|c|c|c|c} 
& \multicolumn{5}{|c|}{ Matched Control 1 } & \multicolumn{4}{c}{ Matched Control 2 } \\
& P/ATC & P/ATC & P/ATC & P/ATC & P/ATC & P/ATC & P/ATC & P/ATC \\
\hline Treatment*Post & 0.043 & 0.024 & 0.032 & 0.006 & $0.06^{* *}$ & 0.040 & $0.06 * *$ & 0.034 \\
& 0.034 & 0.038 & 0.034 & 0.037 & 0.027 & 0.032 & 0.028 & 0.033 \\
Post*Rate & & $0.001^{*}$ & & 0.002 & & $0.0012^{*}$ & & 0.002 \\
& & 0.0006 & & 0.002 & & 0.0007 & & 0.002 \\
Year FE & Yes & Yes & Yes & Yes & Yes & Yes & Yes & Yes \\
Product FE & Yes & Yes & No & No & Yes & Yes & No & No \\
Plant FE & No & No & Yes & Yes & No & No & Yes & Yes \\
Observations & 7,220 & 7,220 & 2,013 & 2,013 & 10,086 & 10,086 & 2,268 & 2,268 \\
R-Squared & 0.32 & 0.32 & 0.70 & 0.70 & 0.31 & 0.37 & 0.70 & 0.70
\end{tabular}

Notes: These tables summarize OLS regression coefficients of plant-level mark-up over ATC on the difference-in-difference interaction term "Treatment*Post" and the effective duty rate interaction term "Post*Rate." Robust standard errors are reported below each coefficient after adjustment for clustering at the plant-level. ***, ** and * represent statistical significance at the $1 \%, 5 \%$ and $10 \%$ levels, respectively. 
Table 11: Antidumping Duties and the Probability of Product-Dropping

\begin{tabular}{l|c|c|c|c}
\multicolumn{1}{c}{ Termination Control Group } \\
& Drop & Drop & Drop & Drop \\
\hline Treatment*Post & $-0.060^{* * *}$ & $-0.062^{* * *}$ & -0.023 & -0.025 \\
& 0.017 & 0.016 & 0.024 & 0.022 \\
Post*Rate & & & $-0.003^{* *}$ & $-0.003^{* *}$ \\
& & & 0.001 & 0.001 \\
Product Shipments & & $-0.076^{* * *}$ & & $-0.076^{* * *}$ \\
& & 0.002 & & 0.002 \\
Product Tenure & & $-0.119^{* * *}$ & & $-0.119^{* * *}$ \\
& & 0.012 & & 0.012 \\
Year FE & & Yes & Yes & Yes \\
Product FE & Yes & Yes & Yes & Yes \\
Observations & 46,742 & 46,742 & 46,742 & 46,742 \\
R-Squared & 0.118 & 0.204 & 0.118 & 0.205
\end{tabular}


Table 11A: Antidumping Duties and the Probability of Product-Dropping Matched Control Group 1

\begin{tabular}{l|c|c|c|c} 
& Drop & Drop & Drop & Drop \\
\hline Treatment*Post & $-0.0515^{* * *}$ & $-0.0445^{* * *}$ & -0.015 & -0.007 \\
& 0.013 & 0.013 & 0.022 & 0.021 \\
Post*Rate & & & $-0.0028^{* *}$ & $-0.0028^{* *}$ \\
& & & 0.001 & 0.001 \\
Product Shipments & & $-0.0475^{* * *}$ & & $-0.0475^{* * *}$ \\
& & 0.007 & & 0.007 \\
Product Tenure & & $-0.1484^{* * *}$ & & $-0.1485^{* * *}$ \\
& & 0.008 & & 0.008 \\
Year FE & Yes & Yes & Yes & Yes \\
Product FE & Yes & Yes & Yes & Yes \\
Observations & 98,166 & 98,166 & 98,166 & 98,166 \\
R-Squared & 0.095 & 0.148 & 0.095 & 0.148
\end{tabular}

Notes: This table summarizes OLS regression coefficients of a binary variable indicating product-dropping (Drop) on the difference-in-difference interaction term "Treatment*Post" and the effective duty rate interaction term "Post*Rate." Robust standard errors are reported below each coefficient after adjustment for clustering at the product-level. $\quad * * *, * *$ and $*$ represent statistical significance at the $1 \%, 5 \%$ and $10 \%$ levels, respectively. 
Table 11B: Antidumping Duties and the Probability of Product-Dropping Matched Control Group 2

\begin{tabular}{l|c|c|c|c} 
& Drop & Drop & Drop & Drop \\
\hline Treatment*Post & $-0.0383^{* *}$ & $-0.0397^{* * *}$ & -0.001 & -0.003 \\
& 0.015 & 0.014 & 0.023 & 0.020 \\
Post*Rate & & & $-0.0028^{* *}$ & $-0.0028^{* *}$ \\
& & & 0.001 & 0.001 \\
Product Shipments & & $-0.0766^{* * *}$ & & $-0.0766^{* * *}$ \\
& & 0.003 & & 0.003 \\
Product Tenure & & $-0.1257^{* * *}$ & & $-0.1258^{* * *}$ \\
& & 0.013 & & 0.013 \\
Year FE & Yes & Yes & Yes & Yes \\
Product FE & Yes & Yes & Yes & Yes \\
Observations & 41,289 & 41,289 & 41,289 & 41,289 \\
R-Squared & 0.106 & 0.197 & 0.106 & 0.197
\end{tabular}

Notes: This table summarizes OLS regression coefficients of a binary variable indicating product-dropping (Drop) on the difference-in-difference interaction term "Treatment*Post" and the effective duty rate interaction term "Post*Rate." Robust standard errors are reported below each coefficient after adjustment for clustering at the product-level. $* * *, * *$ and $*$ represent statistical significance at the $1 \%, 5 \%$ and $10 \%$ levels, respectively. 
Table 12: Antidumping Duties and the Probability of Plant-Level Exit Termination Control Group

\begin{tabular}{|c|c|c|c|c|}
\hline & Exit & Exit & Exit & Exit \\
\hline \multirow[t]{2}{*}{ Treatment*Post } & -0.0018 & 0.0169 & -0.0024 & 0.0029 \\
\hline & 0.0119 & 0.0137 & 0.0119 & 0.015 \\
\hline \multirow[t]{2}{*}{ Post*Rate } & & $-0.0013^{* *}$ & & -0.0004 \\
\hline & & 0.0006 & & 0.0007 \\
\hline \multirow[t]{2}{*}{ No. Employees } & & & $-0.092 * * *$ & $-0.0919 * * *$ \\
\hline & & & 0.0031 & 0.0031 \\
\hline \multirow[t]{2}{*}{ Plant Age } & & & $-0.0022 * * *$ & $-0.0022 * * *$ \\
\hline & & & 0.0004 & 0.0004 \\
\hline \multirow[t]{2}{*}{ Capital Intensity } & & & $-0.0168 * * *$ & $-0.0168 * * *$ \\
\hline & & & 0.0025 & 0.0025 \\
\hline \multirow[t]{2}{*}{ Avg. Wage } & & & $-0.0746^{* * *}$ & $-0.0746^{* * *}$ \\
\hline & & & 0.0077 & 0.0077 \\
\hline \multirow[t]{2}{*}{ Multi-Unit } & & & $0.0934 * * *$ & $0.0934 * * *$ \\
\hline & & & 0.0072 & 0.0072 \\
\hline \multirow[t]{2}{*}{ Multi-Product } & & & $-0.0181 * * *$ & $-0.0181 * * *$ \\
\hline & & & 0.0043 & 0.0043 \\
\hline Year FE & Yes & Yes & Yes & Yes \\
\hline Product FE & Yes & Yes & Yes & Yes \\
\hline Observations & 62,285 & 62,285 & 62,285 & 62,285 \\
\hline R-Squared & 0.059 & 0.059 & 0.116 & 0.116 \\
\hline
\end{tabular}

Notes: This table summarizes OLS regression coefficients of a binary variable indicating plant exit (Exit) on the difference-in-difference interaction term "Treatment*Post" and the effective duty rate interaction term "Post*Rate." Robust standard errors are reported below each coefficient after adjustment for clustering at the productlevel. $* * *, * *$ and * represent statistical significance at the $1 \%, 5 \%$ and $10 \%$ levels, respectively. Control variables are measured at the plant-level. Capital intensity is a plant's book value of capital divided by the number of employees. Average wage is the average annual wage paid to production workers. Multi-unit and multi-product are binary variables that equal one if the plant is part of a multi-unit firm or a producer of multiple products, respectively. 
Table 12A: Antidumping Duties and the Probability of Plant-Level Exit Matched Control Group 1

\begin{tabular}{|c|c|c|c|c|}
\hline & Exit & Exit & Exit & Exit \\
\hline \multirow[t]{2}{*}{ Treatment*Post } & -0.0185 & -0.0024 & -0.0186 & 0.0034 \\
\hline & 0.0145 & 0.0176 & 0.0139 & 0.0154 \\
\hline \multirow[t]{2}{*}{ Post*Rate } & & -0.0012 & & $-0.0017^{* *}$ \\
\hline & & 0.0009 & & 0.0007 \\
\hline \multirow[t]{2}{*}{ No. Employees } & & & $-0.1018 * * *$ & $-0.1018 * * *$ \\
\hline & & & 0.0055 & 0.0055 \\
\hline \multirow[t]{2}{*}{ Plant Age } & & & $-0.0026 * * *$ & $-0.0026 * * *$ \\
\hline & & & 0.0005 & 0.0005 \\
\hline \multirow[t]{2}{*}{ Capital Intensity } & & & $-0.0147 * * *$ & $-0.0147 * * *$ \\
\hline & & & 0.0027 & 0.0027 \\
\hline \multirow[t]{2}{*}{ Avg. Wage } & & & $-0.0696 * * *$ & $-0.0697 * * *$ \\
\hline & & & 0.0105 & 0.0105 \\
\hline \multirow[t]{2}{*}{ Multi-Unit } & & & $0.0779 * * *$ & $0.0779 * * *$ \\
\hline & & & 0.009 & 0.009 \\
\hline \multirow[t]{2}{*}{ Multi-Product } & & & $-0.024 * * *$ & $-0.024 * * *$ \\
\hline & & & 0.0051 & 0.0051 \\
\hline Year FE & Yes & Yes & Yes & Yes \\
\hline Product FE & Yes & Yes & Yes & Yes \\
\hline Observations & 85,617 & 85,617 & 85,617 & 85,617 \\
\hline R-Squared & 0.068 & 0.069 & 0.132 & 0.132 \\
\hline
\end{tabular}

Notes: This table summarizes OLS regression coefficients of a binary variable indicating plant exit (Exit) on the difference-in-difference interaction term "Treatment*Post" and the effective duty rate interaction term "Post*Rate." Robust standard errors are reported below each coefficient after adjustment for clustering at the productlevel. $* * *, * *$ and $*$ represent statistical significance at the $1 \%, 5 \%$ and $10 \%$ levels, respectively. Control variables are measured at the plant-level. Capital intensity is a plant's book value of capital divided by the number of employees. Average wage is the average annual wage paid to production workers. Multi-unit and multiproduct are binary variables that equal one if the plant is part of a multi-unit firm or a producer of multiple products, respectively. 
Table 12B: Antidumping Duties and the Probability of Plant-Level Exit Matched Control Group 2

\begin{tabular}{|c|c|c|c|c|}
\hline & Exit & Exit & Exit & Exit \\
\hline \multirow{2}{*}{ Treatment*Post } & -0.0038 & 0.0162 & -0.0022 & 0.0038 \\
\hline & 0.012 & 0.0135 & 0.012 & 0.0154 \\
\hline \multirow[t]{2}{*}{ Post*Rate } & & $-0.0014 * *$ & & -0.0004 \\
\hline & & 0.0006 & & 0.0007 \\
\hline \multirow[t]{2}{*}{ No. Employees } & & & $-0.0926 * * *$ & $-0.0926 * * *$ \\
\hline & & & 0.0032 & 0.0032 \\
\hline \multirow[t]{2}{*}{ Plant Age } & & & $-0.0021 * * *$ & $-0.0021 * * *$ \\
\hline & & & 0.0004 & 0.0004 \\
\hline \multirow[t]{2}{*}{ Capital Intensity } & & & $-0.016 * * *$ & $-0.016 * * *$ \\
\hline & & & 0.0027 & 0.0027 \\
\hline \multirow[t]{2}{*}{ Avg. Wage } & & & $-0.0714^{* * *}$ & $-0.0715^{* * *}$ \\
\hline & & & 0.0077 & 0.0077 \\
\hline \multirow[t]{2}{*}{ Multi-Unit } & & & $0.0988 * * *$ & $0.0988 * * *$ \\
\hline & & & 0.0077 & 0.0077 \\
\hline \multirow[t]{2}{*}{ Multi-Product } & & & $-0.018 * * *$ & $-0.0179 * * *$ \\
\hline & & & 0.0042 & 0.0042 \\
\hline Year FE & Yes & Yes & Yes & Yes \\
\hline Product FE & Yes & Yes & Yes & Yes \\
\hline Observations & 53,741 & 53,741 & 53,741 & 53,741 \\
\hline R-Squared & 0.046 & 0.046 & 0.102 & 0.102 \\
\hline
\end{tabular}

Notes: This table summarizes OLS regression coefficients of a binary variable indicating plant exit (Exit) on the difference-in-difference interaction term "Treatment*Post" and the effective duty rate interaction term "Post*Rate." Robust standard errors are reported below each coefficient after adjustment for clustering at the productlevel. $* * *, * *$ and * represent statistical significance at the $1 \%, 5 \%$ and $10 \%$ levels, respectively. Control variables are measured at the plant-level. Capital intensity is a plant's book value of capital divided by the number of employees. Average wage is the average annual wage paid to production workers. Multi-unit and multi-product are binary variables that equal one if the plant is part of a multi-unit firm or a producer of multiple products, respectively. 
Table 13: Relative Productivity of Product-Droppers

\begin{tabular}{c|c|c} 
& TFP & LP \\
\hline Drop & $-0.0418^{* * *}$ & $-0.0830^{* * *}$ \\
& 0.0140 & 0.0143 \\
Year FE & Yes & Yes \\
Product FE & Yes & Yes \\
Observations & 44,382 & 44,382 \\
R-Squared & 0.684 & 0.371
\end{tabular}

Notes: This table summarizes OLS regression coefficients of revenue-based total factor productivity (TFP) and labor productivity (LP) on a binary variable indicating whether a plant dropped an investigated product. Robust standard errors are reported below each coefficient after adjustment for clustering at the product-level. $\quad * * *, * *$ and $*$ represent statistical significance at the $1 \%, 5 \%$ and $10 \%$ levels, respectively. 
Table 14: Antidumping Duties and Output Rationalization

\begin{tabular}{c|c|c|c|c|c} 
Year & Post & Treatment & Rationalization & Aggregate & Mean \\
\hline 1987 & 0 & 0 & 0.100 & 1.56 & 1.46 \\
1992 & 0 & 0 & 0.075 & 1.53 & 1.45 \\
1992 & 1 & 0 & 0.187 & 2.03 & 1.85 \\
1997 & 1 & 0 & 0.171 & 1.81 & 1.64 \\
1987 & 0 & 1 & 0.163 & 1.07 & 0.91 \\
1992 & 0 & 1 & 0.176 & 1.33 & 1.15 \\
1992 & 1 & 1 & 0.210 & 1.08 & 0.87 \\
1997 & 1 & 1 & 0.166 & 1.15 & 0.98
\end{tabular}

Notes: This table reports a decomposition of revenue-based total factor productivity by year, post-treatment indicator (Post) and treatment status (Treatment). "Rationalization" is a term measuring the level of output rationalization, as described earlier. "Aggregate" is aggregate productivity. "Mean" is mean plant-level total factor productivity. "Treatment" equals 1 for plants that applied for and received protection and 0 for plants that applied for but did not receive protection. "Post" equals 1 for plants that had already been involved in an antidumping investigation in time $t$ and 0 for plants that had not yet been involved in an investigation. 
Table A.1 Results of Multinomial Logit and Logit Models for Matched Control Groups

\begin{tabular}{|c|c|c|c|}
\hline & \multicolumn{2}{|c|}{ Matched Control Group 1} & \multirow{2}{*}{$\begin{array}{c}\text { Matched } \\
\text { Control } \\
\text { Group } 2 \\
\\
\text { Probability } \\
\text { of Protection }\end{array}$} \\
\hline & $\begin{array}{c}\text { Determinants of } \\
\text { Protection } \\
\text { Given Filing } \\
\end{array}$ & $\begin{array}{c}\text { Determinants of } \\
\text { Termination } \\
\text { Given Filing } \\
\end{array}$ & \\
\hline Lagged Import & & & \\
\hline Penetration & $\begin{array}{c}0.246 * * * \\
0.061\end{array}$ & $\begin{array}{c}-0.202 \\
0.133\end{array}$ & $\begin{array}{c}0.909 * * * \\
0.280\end{array}$ \\
\hline ln(Lagged Employment) & $\begin{array}{c}0.387^{* * * *} \\
0.059\end{array}$ & $\begin{array}{c}0.326^{* * *} \\
0.058\end{array}$ & $\begin{array}{l}0.072 \\
0.091\end{array}$ \\
\hline $\ln$ (Labor Productivity) & $\begin{array}{c}0.210 * * \\
0.101\end{array}$ & $\begin{array}{c}-0.355^{* * *} \\
0.109\end{array}$ & $\begin{array}{c}0.740 * * * \\
0.163\end{array}$ \\
\hline Real GDP Growth & $\begin{array}{l}0.044 \\
0.049\end{array}$ & $\begin{array}{l}0.003 \\
0.045\end{array}$ & $\begin{array}{l}0.024 \\
0.066\end{array}$ \\
\hline Price Growth & $\begin{array}{c}-0.053 * * * \\
0.013\end{array}$ & $\begin{array}{l}-0.017 \\
0.014\end{array}$ & $\begin{array}{c}-0.029 * \\
0.017\end{array}$ \\
\hline Number of Observations & 3,423 & 3,423 & 619 \\
\hline Pseudo-R Squared & $\begin{array}{c}0.03 \\
\text { Multinomial }\end{array}$ & $\begin{array}{c}0.03 \\
\text { Multinomial }\end{array}$ & 0.051 \\
\hline Estimation Technique & Logit & Logit & Logit \\
\hline
\end{tabular}

Notes: This table summarizes estimation results for the multinomial logit and logit models used to generate the two matched control groups. In the multinomial logit model, the dependent variable takes a value of 1 if an industry never filed for protection, 2 if it filed but was turned down for protection and 3 if it applied for and received protection. In the logit model, the dependent variable takes a value of 1 if an industry applied for and received protection and 0 if it applied for, but did not receive protection. Independent variables are at the industry-year-level. $* * *, * *$ and $*$ represent statistical significance at the $1 \%, 5 \%$ and $10 \%$ levels, respectively. 